\title{
The Saint and the Wry-Neck: Norse Crusaders and the Second Crusade
}

During the twelfth century, a Norse tradition developed for participating in the different campaigns instigated by the papacy, later known as the crusades. ${ }^{1}$ This tradition centred on the participation in the crusade campaigns to the Middle East, but not exclusively, as it included crusading activities in or near the Iberian Peninsula and the Mediterranean. By the mid-1150s, the tradition was consolidated by the joint crusade of Earl Rognvald Kolsson of Orkney and the Norwegian magnate and later kingmaker, Erling Ormsson, which followed in the footsteps of the earlier crusade of King Sigurd the Crusader in the early 1100s. The participation in the crusades not only brought Norse crusaders in direct contact with the most holy places in Christendom, but also the transmission of a wide range - political, religious and cultural - of ideas. One of them was to bring back a piece of the holiness of Jerusalem, by various means, in order to create a Jerusalem in the North.

In 1152, a fleet of fifteen large ships from Norway, Orkney and Iceland sailed out from Orkney towards the Holy Land. ${ }^{2}$ The fleet, commanded by the earl and later saint of Orkney, Rognvald Kali Kolsson (r.1136-1158), and the Norwegian "landed man" [lenðir

1 For a general overview of the development of the crusades, see Jonathan Riley-Smith, What Were the Crusades?, fourth ed. (Basingstoke: Palgrave Macmillan, 2009); Norman Housley, Fighting for the Cross: Crusading to the Holy Land (New Haven-London: Yale University Press, 2008); Christopher Tyerman, God's War: A New History of the Crusades (Cambridge MA: The Belknap Press of Harvard University Press, 2006). For the early Scandinavian involvement in the crusades, see Ane Bysted et al., eds., Jerusalem in the North: Denmark and the Baltic Crusades, 1100-1522 (Turnhout: Brepols Publishers, 2012); Janus Møller Jensen, Denmark and the Crusades, c.1400-1650 (Leiden: Brill, 2007). For Norway, see: Pål B. Svenungsen, "Norge og korstogene: En studie av forbindelsene mellom det norske riket og den europeiske korstogsbevegelsen, ca. 1050-1380" (PhD Thesis, University of Bergen, 2016). See also the comprehensive, but outdated study by Paul Riant, Expéditions et pèlerinages des Scandinaves en Terre Sainte au temps des croisades, 2 vols. (Paris: impr. de A. Lainé et J. Havard, 1865-1869) (also in Danish translation Skandinavernes Korstog og Andagtsreiser til Palæstina (1000-1350) (Copenhagen: Schubothes Boghandel, 1868)).

2 The main source to the expedition is the Orkneyinga saga (ch. 85-89) Orkneyinga saga, ed. S. Nordal, Copenhagen: Samfund til Udgivelse af gammel nordisk Litteratur, 1913-1916; Orkneyinga Saga: The History of the Earls of Orkney, trans. Hermann Pálsson and Paul Edwards, London: Penguin Classics, 1978. Several Icelandic sources date the journey to 1151, but Arne Odd Johnsen argued, based on the chronology of the Orkneyinga saga, that this date must refer to the fleet's departure from Norway, not

Pål Berg Svenungsen, Associate Professor of History, Western Norway University of Applied Sciences

Ә Open Access. (C) 2021 Pål Berg Svenungsen, published by De Gruyter. (c) BY-NC-ND This work is licensed under the Creative Commons Attribution-NonCommercial-NoDerivatives 4.0 International License.

https://doi.org/10.1515/9783110639438-007 
maðir] and later kingmaker Erling Ormsson skakki (“Wry-neck”, d. 1179), was hence a representation of the widespread Norse community. ${ }^{3}$ The expedition followed a pattern of religious motivated journeys from Western Europe to the Levant during the twelfth and thirteenth centuries, later referred to as the crusades. The two Jerusalems, earthly and heavenly, had a central place in the sacred topography of Christendom, and following the First Crusade in the late eleventh century, the notion of Jerusalem was to dominate the religious, political and cultural life in Europe for centuries. ${ }^{4}$ The crusades began when Pope Urban II (r. 1088-1099) called for a new kind of pilgrimage at a council in Clermont in 1095, namely an armed pilgrimage to liberate Jerusalem. ${ }^{5}$ The following campaign culminated four years later with the capture of Jerusalem and the establishment of a Latin kingdom.

Pope Urban II tapped into strong religious undercurrents in Europe, such as eschatological ideas and the pilgrimage tradition, with a strong focus on Jerusalem and notions of imitating Christ (imitatio Christi). ${ }^{6}$ By this, the crusades represented a fusion between different Christian traditions, especially the pilgrimage tradition with the twin notions of holy and just warfare, and in this way transforming warfare into a penitential act. ${ }^{7}$ The new ideas were strongly connected with the reform movement within the church, but its message transcended societal boundaries and became immensely popular. However, the first crusaders only got rudimentary guidance from the Pope and adapted the crusade according to their own fears, ambitions, and motivations. ${ }^{8}$ From early on, the crusades became associated with powerful images such

Orkney, where the fleet first wintered, see Arne Odd Johnsen, Studier vedrørende kardinal Nicolaus Brekespears legasjon til Norden (Oslo: Fabritius \& Sønners Forlag, 1945), 387-414.

3 The terms "Norse community" and "Norse" are used here to denote the areas with strong historical and political ties, as well as cultural and linguistic connections, to the Norwegian kingdom in the Middle Ages. In medieval Norwegian law the Norse community is defined as consisting of two parts: the Norwegian king's realm [Noregs veldi] and his tax lands [skattland]. Besides the Norwegian mainland, this included Iceland, Greenland, Orkney, the Faroe Islands, the Isle of Man, Shetland and the Hebrides. For an overview, see Jón Viðar Sigurdsson, "The Norse Community," in The Norwegian Domination and the Norse World c.1100-1400, ed. Steinar Imsen (Trondheim: Tapir Academic Press, 2010), 59-73.

4 For the long tradition of pilgrimage to the Holy Sepulchre, see Colin Morris, The Sepulchre of Christ and the Medieval West (Oxford: Oxford University Press, 2005).

5 Cf. Jonathan Riley-Smith, The First Crusade and the Idea of Crusading (Philadelphia: University of Pennsylvania Press, 1986).

6 William J. Purkis, Crusading Spirituality in the Holy Land and Iberia, c.1095-c.1187 (Woodbridge: The Boydell Press, 2008), 35-58. For the eschatological backdrop of the First Crusade, see Jay Rubenstein, Armies of Heaven: The First Crusade and the Quest for the Apocalypse (New York: Basic Books, 2011).

7 Riley-Smith, The First Crusade; Carl Erdmann, The Origin of the Idea of Crusade, trans. M.W. Baldwin and Walter Goffart (Princeton: Princeton University Press, 1977); Frederick H. Russell, The Just War in the Middle Ages (Cambridge: Cambridge University Press, 1975).

8 Housley, Fighting for the Cross, 2-3. 
as love, vengeance, or even feudal service to Christ. ${ }^{9}$ Starting as a series of campaigns authorised by the papacy and preached by the church, it took nearly a century before the crusades matured into a coherent and streamlined movement. ${ }^{10}$ Nevertheless, by the mid-twelfth century crusade-like expeditions were already exported to new arenas such as Iberia, the Baltic, and other places in Europe.

In early Norse crusading history, there are two major campaigns that set out from Norway in the first half of the twelfth century and share strong narrative parallels: the crusade of King Sigurd jórsalafari (literally “Jerusalem-traveller”) in 1108-1111 and that of Earl Rognvald in 1152-1155. These campaigns brought back relics and new ideas that underline the important place of Jerusalem in Norse lay religiosity in the twelfth century. ${ }^{11}$ The aim of this chapter is hence twofold. First, it aims to study how the expedition of Rongvald and Erling fits within the wider context of twelfth-century crusading as well as in the narrow context of their region. Second, it aims to study how participation in the crusades brought Norse crusaders in contact with new ideas - especially connected to Jerusalem - and how their impressions were absorbed and given a Norse expression. I will start, however, with a short overview of the historiography of the crusades in Norway.

\section{The Historiographical Tradition - or Lack Thereof}

The crusades have been described as one of the major forces in European history. ${ }^{12}$ The First Crusade began as a predominantly Frankish undertaking, with the majority of the preaching and recruitment carried out in French speaking areas. ${ }^{13}$ Nevertheless, contemporary chroniclers like the Norman Ordericus Vitalis (d. 1142), underlined the universal character of the enterprise and emphasised how Pope Urban's speech resonated "throughout the world."14 Scandinavians participated in the crusades from an early stage, and were perhaps even among the first armies

9 Riley-Smith, What Were the Crusades? 9, 11, 27, 43, 55, 81; Housley, Fighting for the Cross, 86-98. 10 Riley-Smith, What Were the Crusades?; Christopher Tyerman, The Invention of the Crusades (Basingstoke: Palgrave Macmillan, 1998).

11 Cf. Chapter 8 (Lukas Raupp), 140-65.

12 Riley-Smith, What Were the Crusades?, 1.

13 Pope Urban II descended from a minor noble family in the Champagne region of France. After the council of Clermont ended, he continued to tour the French domains attending local festivals and markets, preaching and recruiting to the crusade. For an itinerary of Urban's recruitment tour, see Alfons Becker, Papst Urban II. (1088-1099). Teil 2: Der Papst, die griechische Christenheit und der Kreuzzug, Stuttgart: Hiersemann, 1988.

14 “. . . per totum orbem," Ordericus Vitalis, The Ecclesiastical History of Ordericus Vitalis, 6 vols, ed. and trans. M. Chibnall, Oxford: Oxford University Press, 1969-1975. 
that set out towards Jerusalem in $1096 .{ }^{15}$ In a reference to a group of Scottish crusaders participating in the First Crusade, the Benedictine abbot and historian Guibert of Nogent (d. 1124), also included a reference to another group of crusaders he regarded as unintelligible "barbarians." very well have been Scandinavian crusaders. ${ }^{17}$

Despite many references to Scandinavian involvement in the crusades in a wide range of medieval sources - including in Scandinavian, European, and even Arabic sources - the crusades have received little attention in Scandinavian, and especially in Norwegian, historiography. ${ }^{18}$ During the nineteenth and early twentieth centuries, the crusades did not fit well within the nation-building project which dominated the historiography of this period. ${ }^{19}$ There was a need to create a history for the young Norwegian state, recently independent from centuries of Danish and Swedish rule, which fostered a national paradigm, coloured by Protestant inclinations, within which historians sought to prove how Norway differed not only from neighbouring Sweden and Denmark, but also from Europe in general. In this Norwegian Sonderweg, European (i.e. Catholic) influence on the medieval Norwegian kingdom was downplayed. In the first half of the twentieth century, Marxist materialistic theory of history was very influential on Norwegian historiography. One would perhaps expect that the Marxist influence would make Norwegian historians more likely to frame the Norse crusade expeditions as military-economic endeavours. However,

15 In his chronicle of the First Crusade, Albert of Aachen included the tragic story of the Danish prince Svend. He was a son of the Danish King Svend Estridsen, who, accordingly, killed in an ambush in Anatolia along with his fiancé Florina, a daughter of the Duke of Burgundy, and 1500 of his men, see Albert of Aachen, Historia Ierosolimitana, ed. and trans. Susan B. Edgington, Oxford Medieval Texts, Oxford: Clarendon Press, 2007. See also Chapter 1 (Kristin B. Aavitsland), 29.

16 It was only when these barbarians made the sign of the cross with their fingers, that the Franks understood they had come to participate in the Crusade, see Guibert av Nogent, The Deeds of the Franks Franks [Gesta Dei per Francos], trans. R. Levine, Woodbridge: The Boydell Press, 1997.

17 In an often quoted passage, the English chronicler William of Malmesbury (d. 1143), recalled how Urban's call had left forests and fields empty across Europe, "the Welshman gave up hunting in his forests, the Scotsman forsook his familiar fleas, the Dane broke of his long drawn-out potations, the Norwegian left his diet of raw fish”, William of Malmesbury, Gesta Regum Anglorum: The History of the English Kings, 2 vols, ed. and trans. R.M. Thomson and M. Winterbottom, Oxford: Oxford University Press, 2007.

18 Until quite recently the only comprehensive academic study of Norwegian involvement and participation in the crusades, was the doctoral thesis the French count Paul Riant submitted at Sorbonne in 1865, see Riant, Expéditions et pèlerinages des Scandinaves en Terre Sainte. For an overview of Norwegian crusade historiography, see Svenungsen, "Norge og korstogene," 16-20. For an overview of Danish crusade historiography, see Jensen, Denmark and the Crusades, 1-24.

19 For a general overview of Norwegian historiography, see Sverre Bagge, "The Middle Ages," in Making A Historical Culture: Historiography in Norway, ed. W.H. Hubbard, et al. (Oslo: Scandinavian University Press, 1995). 
they did not. ${ }^{20}$ An evaluation of Norwegian historiography, commissioned by The Research Council of Norway (RCN) in 2008, concluded that much of Norwegian historical research was still in the vein of methodological nationalism. ${ }^{21}$ The conclusion of this evaluation was hotly debated among Norwegian historians, ${ }^{22}$ but even if the evaluation might exaggerate tendencies within recent Norwegian historiography, it may serve as an indicator as to why such an international topic as the crusades still receives so little attention in Norway. For whatever reason, the fact remains that the crusades are only treated in passing or anecdotally - if mentioned at all - in most studies on Norwegian medieval history. ${ }^{23}$

Another tendency concerning the Norse expeditions to the Holy Land in the twelfth and thirteenth centuries has been that Norwegian historians generally emphasize Constantinople, not Jerusalem, as the primary destination of expeditions to the Eastern Mediterranean. ${ }^{24}$ This tendency, however, places the expeditions within the context of the longstanding tradition of Scandinavians seeking mercenary service in the Byzantine army rather than within a crusade context. ${ }^{25}$ In crusade historiography in general, the earlier materialistic explanation has come under attack. ${ }^{26}$ Instead, ideology and religion are now taken seriously as important motivational factors in their own right. ${ }^{27}$ This revision does not entail, however, that historians

20 As Norman Housley points out, Marxist historians in general did not engage with the subject of the structural explanations of the crusades, see Norman Housley, Contesting the Crusades (Malden: Wiley-Blackwell, 2006), 77-8.

21 Anette Elisabeth Warring et al., eds., Evaluering av norsk historiefaglig forskning: bortenfor nasjonen i tid og rom: fortidens makt og fremtidens muligheter i norsk historieforskning (Oslo: Norges forskningsråd, 2008).

22 Cf. Knut Kjeldstadli, “Å evaluere evaluatørene,” Historisk Tidsskrift 88 (2009).

23 The tendency becomes evident when one studies the indexes in recent overviews in medieval Norwegian history, research journals or conference programs for words like "crusades" or "crusading”, which are close to non-existing.

24 Geir Atle Ersland, "Eit statsbesøk til Konstantinopel via Jerusalem," in Fragment frå fortida, ed. Geir Atle Ersland and Øystein H. Brekke (Bergen: Dreyers forlag, 2013), 24-37. See also Arnved Nedkvitne, "Why Did Medieval Norsemen Go on Crusade?," in Medieval History Writing and Crusading Ideology, ed. T.M.S. Lehtonen, et al. (Helsinki: Finnish Literature Society, 2005).

25 For the Varangian Guard, see Roland Scheel, Skandinavien Und Byzanz: Bedingungen Und Konsequenzen Mittelalterlicher Kulturbeziehungen, 2 vols., Historische Semantik (Göttingen: Vandenhoeck Ruprecht, 2015); Sigfús Blöndal, The Varangians of Byzantium: An Aspect of Byzantine Military History, ed. Benedikt S. Benedikz, trans. Benedikt S. Benedikz (Cambridge: Cambridge University Press, 1978).

26 For recent tendencies in the international historiography on the crusades, see Christopher Tyerman, The Debate on the Crusades, 1099-2010, Issues in Historiography (Manchester: Manchester University Press, 2011). See also Housley, Contesting the Crusades.

27 Marcus Bull's study of lay piety pointed out the deep religious sentiments within the European aristocracy already before the crusades in the eleventh century, see Marucs Bull, Knightly Piety and the Lay Response to the First Crusade: The Limousin and Gascony c.970-c.1130 (Oxford: Oxford University Press, 1993). 
see participation as solely driven by religious sentiments. Rather, it implies a recognition of the need to re-evaluate the evidence and present a more nuanced view of the role of the crusades in Norwegian medieval history.

This chapter will mainly focus on the ideological perspective of Norse twelfthcentury Mediterranean expeditions. It argues that Rognvald's expedition must be situated within the context of the crusades, perhaps as a late Norse response to Pope Eugenius III's call for a general crusade (passagium generale) which is now known as the Second Crusade. ${ }^{28}$ But before the expedition of Earl Rognvald and Erling can be discussed, it is important to look at the issue of terminology and how crusading should be understood, both within an international and a Norse context.

\section{The Issue of Definition: Crusading in a Norse Context}

The question of whether the joint expedition of Earl Rognvald and Erling Ormsson falls within the definition of a crusade is not easy to determine. There are two main challenges for this situation. First, there is the challenge of terminology. The novelty of the First Crusade is evident by the fact that contemporaries, including Pope Urban II, lacked a clear vocabulary to draw on. As several scholars have pointed out, there was no single word that can be translated as "crusade," either in Latin or in the vernaculars, until quite late in the history of the crusades. ${ }^{29}$ Urban II had

28 For a further discussion of the Second Crusade and Scandinavia, see Janus Møller Jensen, "The Second Crusade and the Significance of Crusading in Scandinavia and the North Atlantic Region," in The Second Crusade: Holy War on the Periphery of Latin Christendom, ed. J.T. Roche and Janus Møller Jensen (Turnhout: Brepols Publishers, 2015), 155-81.

29 Instead, the early vocabulary of the crusades borrowed from terms associated with pilgrimage [peregrinatio] or with certain aspects of crusading, such as indicating movement or travel [iter, via, expeditio, and later passagium], or corresponding verbs combined with a reference to Jerusalem, the holy sites or the cross [negotium Terrae Sanctae or Christi]. Often, they expressed a religious engagement or desire [negotium, bellum, causa, opus, voluntas, or crux], and referred to its sacred character or to God, Christ or Jerusalem. Not until the early thirteenth century did terms like cro$z a d a$ appear in Spain and south-western France, but its use remained rare, as did croiserie and croisade, while the English crusade was not common before the seventeenth century, see Giles Constable, "The Historiography of the Crusades," in The Crusades from the Perspectives of Byzantium and the Muslim World, ed. A.E. Laiou and R.P. Mottahedeh (Washington DC: Dumbarton Oaks, 2001), 11-12. In Old Norse, the term usually used to refer to a crusade was jórsalaferð (a travel to Jerusalem) and other words associated with travel [ferð or útferð], even if these could also refer to a pilgrimage. It was only in the thirteenth century that more specific terms associated with the act of taking the cross, such as krossa sik (to take the cross), appear in the sources. The modern Norwegian term for a crusade, korstog, did not appear in Danish and Norwegian until the second half of the eighteenth century as a direct translation of the German Kreuzzug, see Svenungsen, 
called for an armed pilgrimage, but he did not exactly know what he had created. It would take nearly a century before scholars and theologians had fully mapped out the concept of the crusades, as an idea and in practice, judicially and spiritually. ${ }^{30}$ Somewhat related to the challenge of terminology are the historiographical problems caused by the volatile character of the First Crusade.

The second challenge is the lack of consensus in modern crusade studies. Traditionally, only campaigns to conquer or defend Jerusalem during the Middle Ages were regarded as "real" crusades. Nevertheless, historians always knew crusades were directed to other places as well, but these campaigns were seen as mere "perversions" of the original idea. This traditionalist paradigm, however, came under attack in the 1970s, and a revision led to a fragmentation of the field into different historiographical "schools," each emphasizing different aspects of the phenomenon. Currently, there is no consensus for one undisputed definition of what the crusades actually were. ${ }^{31}$ The leading definition in most modern studies, the so-called "pluralist" definition, requires certain key elements in the sources: the presence of papal authority, to which at least some of the participants swore an oath, the presence of certain insignias (cloth crosses), and the promise that the participants were granted certain legal and spiritual privileges by the church. ${ }^{32}$ If understood in its most rigid form, the pluralist definition would exclude labelling the expedition of Earl Rognvald and Erling Ormsson as a proper crusade. ${ }^{33}$

However, some historians associated with this pluralist definition have pointed out that too strict of an application runs the danger of neglecting a wide range of phenomena that contemporaries clearly associated with the "essence of crusading." 34 This is especially the case during the formative twelfth century, when crusading was largely a series of incoherent campaigns, before it matured into a more

\footnotetext{
"Norge og korstogene," 11-14; Janus Møller Jensen, "Denmark and the Holy War: A Redefinition of a Traditional Pattern of Conflict, 1147-1169," in Scandinavia and Europe 800-1350: Contact, Conflict and Coexistence, ed. Jonathan Adams and Katherine Holman (Turnhout: Brepols Publishers, 2003). 30 Cf. Tyerman, The Invention of the Crusades.

31 For an overview of the different terms associated with crusading and the different historiographical "schools," see Constable, "The Historiography of the Crusades," 11-2; Housley, Contesting the Crusades, 2-23.

32 Riley-Smith, What Were the Crusades?.

33 While the terminology used in the pluralist definition is mostly lifted from Latin chronicles from the continent written by clergymen and using the vocabulary of the Church, the Norse sagas were mostly written by and for a secular audience, employing the vernacular vocabulary of a mainly warrior aristocracy.

34 Constable, "The Historiography of the Crusades," 12-3. Another historian is Norman Housley, who has pointed out that it might be possible to combine elements of pluralism with that of another school of thought, generalism, which "softens pluralism's edges," see Housley, Contesting the Crusades, 20-1.
} 
coherent and streamlined movement around $1200 .{ }^{35}$ It may then be more reasonable to apply a broader understanding of the pluralist definition. Again, the paucity of the sources makes this difficult to determine, but in order to get closer to an answer, I will apply William Purkis's simple, yet very functional, distinction. Purkis argues that when an individual's travel is known to be primarily devotional, he or she was a pilgrim, and when primarily military, a crusader. ${ }^{36}$ I will come back to how this distinction might help us to get a better understanding of the character of Rognvald and Erling's expedition, but before turning to the sources, it is relevant to present a short overview of the early period of the Norse involvement in the crusades.

\section{Was There a Norse Crusade Tradition in the Twelfth Century?}

Different conceptions of Jerusalem were featured throughout the history of the crusades, mainly as a set of biblical metaphors, in what could be conceived of as the medieval Jerusalem code. ${ }^{37}$ Perhaps the most powerful concept was that of "the two Jerusalems," which combined the geographical centre of the Christian storyworld with eschatological expectations. The first was the earthly Jerusalem, the physical place where Christ had lived, died and, according to the faithful, resurrected. The other city was the eternal Jerusalem, a heavenly copy of the earthly city. With all its holy places and shrines, Jerusalem had long been a goal for pilgrims and pilgrimage from the Latin West from the fourth century and onwards. ${ }^{38}$ While crusading was a devotional act on par with the pilgrimage, it was also a form of warfare directly connecting the crusader to the two Jerusalems - by fighting for the earthly city, the crusader gained entry into the heavenly Jerusalem. ${ }^{39}$

Scandinavians had a long history of undertaking long voyages. The earliest history of Scandinavian travel to Jerusalem is not recorded, but might well predate the

35 Tyerman, The Invention of the Crusades.

36 Purkis, Crusading Spirituality, 6.

37 Cf. Prelude, 3-6, and the introduction in Chapter 1 (Kristin B. Aavitsland), 17-24. Norman Housley points out the difficulty to fully grasp the phenomenon, as "[s]ome of the 'Jerusalems' that this entailed - the allegorical (representing the Church), anagogical (prefiguring heaven) and tropological (symbolizing the individual's soul) - overlap and defy precise analysis," see Housley, Contesting the Crusades: 87.

38 The first known pilgrimage from Western Europe to Jerusalem, was a pilgrimage from Bordeaux in 333, see John Wilkinson, Joyce Hill, and W. F. Ryan, eds., Jerusalem Pilgrimage 1099-1185 (London: Hackluyt Society, second series 167, 1988). See also Morris, The Sepulchre of Christ.

39 Housley, Fighting for the Cross, 26-7. 
Christian conversion of Scandinavia. ${ }^{40}$ Journeys from Scandinavia to the Levant were probably undertaken for a wide range of reasons. The motivation could be religion, trade, military service, or simply exploration out of curiosity - as is reflected in the later saga accounts of Norse long distance travellers. ${ }^{41}$ Christian Krötzl argues that there was a period of transition in which these kinds of multi-purpose travels were transformed into Christian pilgrimages. ${ }^{42}$ While Rome was the most important destination for Scandinavian elite pilgrims in the eleventh century, due to political circumstances, ${ }^{43}$ other destinations, such as Santiago de Compostella and Jerusalem, became more popular in the following century. By the mid-twelfth century there even was a literary genre of "travel guides" for pilgrims in the Old Norse vernacular, the so-called leiðarvísir. ${ }^{44}$ The development of an indigenous cult of local saints increased the number of pilgrimages within Scandinavia, such as to the shrine of St Olav in Nidaros. In the thirteenth century, the Mamlukes' conquest of the Levant made pilgrimage to Jerusalem, at least for a time, more difficult.

So when did Scandinavian pilgrimage transform into armed pilgrimage, or crusade? In the first half of the thirteenth century there seems to be a memory in the Norse sagas of Norse crusading to Jerusalem even predating the First Crusade. According to the two Norse kings' sagas, Morkinskinna (c.1220) and Snorri's Heimskringla (c.1230), the famous Norwegian king and Varangian Harald harðráða (Hard-ruler, r.1047-1066) had undertaken an armed pilgrimage to liberate Jerusalem before he became king. ${ }^{45}$

40 Short inscriptions on Swedish rune stones dating from the tenth and eleventh century, refer to journeys to Jerusalem, see Rune Edberg, "Spår efter en tidlig Jerusalemfärd," Fornvännen 101 (2006): 343. For an overview of the Scandinavian pilgrimage tradition, see Christian Krötzl, Pilger, Mirkalen und Alltog. Formen des Verhaltens im Skandinavischen Mittelalter (12.-15. Jahrhundert) (Helsinki: Serie: Studia historica, 1994).

41 In many of the saga accounts of Norse far travellers there are references to pilgrim sites, see John D. Shafer, "Saga-Accounts of Norse Far-Travellers" (PhD Thesis, Durham University, 2010). See also Chapter 12 (Stefka G. Eriksen), 218-43.

42 Krötzl, Pilger, Mirkalen und Alltog, 102-3.

43 In 1027, Knud the Great travelled to Rome, where he combined a pilgrimage with partaking in the imperial coronation of Conrad II.

44 A few years prior to the earl's expedition, the Icelandic monk and later abbot of Pverá, Nikulás Bergsson (d. 1160), made a journey to Jerusalem and wrote about his travel. See Chapter 11 (Denys Pringle), 203-7 and Chapter 13 (Stefka G. Eriksen), 218-83.

45 None of the sagas date the expedition. Allegedly, it must have occurred in the 1030s or 1040s, when Harald was in employment of the Greek emperor, see Snorri Sturluson, Heimskringla, 3 vols, trans. Alison Finlay and Anthony Faulkes, London: Viking Society for Northern Research, University College London, 2016, vol. 3, Haralds saga Sigurðarsonar; Morkinskinna: The Earliest Icelandic Chronicle of the Norwegian Kings (1030-1157), trans. Theodore Andersson and Kari Ellen Gade, Ithaca-London: Cornell University Press, 2000. 
Both sagas refer to Harald as a pálmara, the Norse word for pilgrim, but the motives presented for the journey are conflicting in the two sagas. ${ }^{46}$

The saga authors clearly had limited knowledge about the reasons for Harald's expedition. ${ }^{47}$ Sigfus Blöndal argues that Harald was most likely sent to Jerusalem as escort for a group of high-ranking Byzantine pilgrims. ${ }^{48}$ This seems plausible. The literary rendering of Harald's armed pilgrimage may testify to an influence from French and German historians, who in the course of the twelfth century, had transformed Charlemagne into the archetype crusader. ${ }^{49}$ The description of King Harald's "proto-crusade" seems cast in the same mould. ${ }^{50}$ The depiction of Harald as a liberator of the Holy Land and the defender of pilgrims seems heavily influenced by contemporary crusade ideology and crusade institutions like the Knights Templars. ${ }^{51}$ This memory construct served different purposes. Not only did it place Norse crusading on par with the continental tradition, it also - more importantly - made Norwegian kings look better than their Danish rivals. ${ }^{52}$

While some modern historians reject the idea that there even existed something like a crusade movement in the twelfth century, ${ }^{53}$ something definitely developed that could be called a Norse crusade tradition, or at least pattern, centred on the participation in the crusades to Jerusalem. This participation, which also included other crusade venues such as Iberia, was concurrently transforming warfare at home. In the 1120s, elements of crusading ideology seem to have influenced King Sigurd's punitive expedition against apostates in Kalmar (Scania); while later, in

46 Morkinskinna claims Harald went to Jerusalem to atone for some sin, Morkinskinna, ch. 13. The Heimskringla referred to the skaldic tradition, which claimed Harald was sent there by the Emperor, Snorri Sturluson, Heimskringla: vol. 3, Haralds saga Sigurðarsonar, ch. 12.

47 For the sagas, see Claus Krag, "Harald Hardrådes ungdomsår og kongesagaene: Forholdet mellom sagaprosa, skaldekvad og muntlig tradisjon," Collegium Medievale. Interdisciplinary Journal of Medieval Research 11 (1998): 9-31.

48 Blöndal, The Varangians of Byzantium, 57-8.

49 Matthew Gabriele, An Empire of Memory: The Legend of Charlemagne, the Franks, and Jerusalem before the First Crusade (Oxford: Oxford University Press, 2011), 128. See aslo Chapter 5 (Bjørn Bandlien), 73-77 on the reception of the figure of Charlemagne.

50 This might have been influenced by the place crusading had achieved in royal ideology by the thirteenth century. Many of the King's sagas were written in the 1220s and 1230s, which coincide with the attempts of King Haakon Haakonsson (r. 1217-1263) to get a papal coronation. Consequently, he made several vows to go on a crusade. The crusades played an important part in Haakon's diplomatic relations with the papacy, but also other foreign leaders, see: Svenungsen, "Norge og korstogene," 151-77. 51 The sagas's depictions of Harald might have been influenced by the situation after the Muslim conquest of Jerusalem in 1187, see Svenungsen, “Norge og korstogene," 44-8.

52 King Erik of Denmark had been the first Scandinavian monarch to set sail towards Jerusalem in the aftermath of the First Crusade and a recurrent topos in several Norse King's sagas is to contrast his journey with the later crusade of King Sigurd. This is especially evident in connection with the stay in Constantinople. Both kings were given a choice of gift by the Byzantine Emperor, between tubes of gold and games held in their honour at the Hippodrome. While the Danish king chose the gold, King Sigurd instead chose the games, which presented him as the more honourable, see Morkinskinna, ch. 62.

53 Tyerman, The Invention of the Crusades. 
the 1160s, elements of crusading ideology were incorporated in the defence of King Magnus Erlingsson's reign. ${ }^{54}$ The beginning of Norse participation in the crusades dates back to the time of the First Crusade. King Sigurd jórsalafari's crusade in 1108 was perhaps a late wave of the First Crusade, but he also became the first European monarch to visit Jerusalem after the conquest and the establishment of a Latin kingdom. ${ }^{55}$ The crusade might have been the result of the extensive contact with the British Isles, where the First crusade was widely known. ${ }^{56}$ The crusade could also have been a response to the earlier pilgrimage or crusade of the Danish King, Erik the Good, who was the first monarch to set out towards Jerusalem, but died en route at Cyprus in $1103 .^{57}$

King Sigurd, however, might not have been the first Norse crusader. Already in 1103, a group of Norsemen who had participated in a voyage to the Holy Land and Constantinople had returned to Norway. Two years earlier, Skopti Qgmundarson, a magnate in Western Norway from the powerful Arnunge family, set out for Jerusalem accompanied by three of his four sons and a well-equipped fleet of five ships and many men. Neither Skopti nor any of his three sons, however, made it to Jerusalem, as they all died on the way. ${ }^{58}$ According to Snorri Sturluson (d. 1241), who is the only source to Skopti's expedition, the journey was the result of a conflict between Skopti and the Norwegian King Magnus Barefoot (r. 1093-1103). Snorri's account of the conflict is not very convincing. ${ }^{59}$ If the saga's reference to

54 The so-called "Kalmar-leidang" of 1123/24, a joint military expedition by King Sigurd and his Danish counterpart, King Niels, against apostate Christians in Småland. Whether the expedition was a crusade is difficult to determine from the few sources, but the later saga authors were at least influenced by contemporary crusading themes. However, one indication that at least some contemporaries saw it as a crusade is an undated letter from Peter the Venerable, the abbot of Cluny, to King Sigurd. In his letter, the abbot praise the king for his efforts to fight "the enemies of Cross of Christ" [inimicos crucis Christi] at home and in the East and South, see Latinske dokument til norsk middelalder fram til 1204, ed. E. Vandvik, Oslo: Samlaget, 1959, No. 4. See also Kurt Villads Jensen, Crusading at the Edges of Europe: Denmark and Portugal c.1000-c.1250 (London: Routledge, 2016), 170-3.

55 For an overview of King Sigurd's crusade, see Svenungsen, "Norge og korstogene," 65-8.

56 Christopher Tyerman, England and the Crusades, 1095-1588 (Chicago - London: The University of Chicago Press, 1988), 24-32.

57 King Erik's journey is mentioned in the Norse King's saga Knytlinga Saga: The History of the Kings of Denmark, trans. Hermann Pálsson and Paul Edwards, Odense: Odense University Press, 1986, and the Latin chronicle of Saxo Grammaticus, Saxos Danmarks Historie, 2 vols, trans. Peter Zeeberg, Copenhagen: Gads Forlag, 2000. See also Chapter 8 (Lukas Raupp), 147-64 and Chapter 11 (Pringle), 199-204.

58 Skopti himself died in Rome while his last remaining son, Thord, died in Sicily, see Snorri Sturluson, Heimskringla: vol. 3, Magnuss saga Berfoetts, ch. 17-20. See also Svenungsen, "Norge og korstogene," 60.

59 In Snorri's account, the reason for the conflict between Skopti and King Magnus is a quarrel over dánararf, which was either an inheritance a buried treasure. When the conflict escalated, each of Skopti's sons visit the king three times. Since the number three is a magic number in Scandinavian 
"well-equipped" [vel búin] is understood in military terms, this might indicate that they represented the first wave of Norse crusaders. ${ }^{60}$

In April 1147, Pope Eugenius III (r. 1145-1153) published his bull Divina dispensatione (II). This gave crusaders going to Iberia and the Baltic the same privileges as participants in the Jerusalem crusade. ${ }^{61}$ For centuries onwards, different Danish, Swedish, German and Polish agents rivalled for hegemony in the Baltic region. ${ }^{62}$ There is, however, little evidence that Norwegians were involved in the Baltic crusade and mission in the twelfth century. ${ }^{63}$ There might be several reasons for this, but one crucial factor might be that a Norse crusade tradition focusing on Jerusalem had already developed. ${ }^{64}$ This, however, does not mean that Norse crusading fits with the understanding of the so-called "traditionalists," who views only campaigns fought to liberate or defend Jerusalem as real crusades. ${ }^{65}$ That being said, Norse crusaders seem to have had a more pragmatic attitude, where they regularly participated in crusading activities in Iberia underway to Jerusalem. ${ }^{66}$

folktales, it was perhaps introduced by Snorri in an effort to create a coherent story from fragmented sources.

60 Another contemporary voyage to Jerusalem, was the pilgrimage (or crusade?) of Lagman, the ruler of Man which is mentioned in the Chronicle of the Kings of Man. According to the chronicle, Lagman went to Jerusalem in the 1090s or early 1100s (the chronology of the chronicle is very uncertain), perhaps as penance for the mutilation of a younger brother, see Svenungsen, "Norge og korstogene," $56-7$.

61 For a general overview of the Second Crusade, see Jonathan Phillips, The Second Crusade: Extending the frontiers of Christendom (New Haven-London: Yale University Press, 2007). For the sources to the crusade, see Giles Constable, "The Second Crusade as seen by Contemporaries," Traditio 9 (1952): 213-79.

62 For an overview of the Baltic Crusades, see Eric Christiansen, The Northern Crusades (London: Penguin Books, 1997). See also Iben Fonnesberg-Schmidt, The Popes and the Baltic Crusades 1147-1254 (Leiden: Brill, 2007).

63 The Papacy clearly sought Norwegian involvement in the Baltic crusades, perhaps to balance German or Danish dominance, but a papal letter, dating from 1171-1172, urging Norwegian participants to partake in a crusade against the pagan Estonians, does not seem to have resulted in any Norwegian response, see DN vol. 17, 854.

64 An obvious reason is the political turmoil in Norway during the majority of the twelfth century, but it might also be the result of lack of surviving sources.

65 Housley, Contesting the Crusades.

66 In fact, according to the narrative sources the actual fighting, the "crusading bit" of these expeditions, were done in or near Iberia, see Svenungsen, "Norge og korstogene," 64-149. For the raids on the Balearic Islands, see Gary B. Doxey, "Norwegian Crusaders and the Balearic Islands," Scandinavian Studies 68 (1996): 139-60. 


\section{The Source Material}

There is a pronounced difference in the source material relating to the earlier crusade of King Sigurd compared to that of Earl Rognvald and Erling Ormsson, as the former crusade is recorded in a wide range of Scandinavian and non-Scandinavian sources, including eyewitness accounts. ${ }^{67}$ In contrast, the latter is only recorded in a handful of Scandinavian sources, including several shorter summaries in the Norse King's sagas and Icelandic annals. ${ }^{68}$ The main narrative source for Rongvald and Erling's expedition is the Orkneyinga saga, written by an unknown Icelander around $1200 .{ }^{69}$ None of these sources are contemporary, some are written even centuries later. The Orkneyinga saga, however, contains several skaldic poems attributed to named participants, including Earl Rognvald. These poems are usually regarded as eyewitness accounts. ${ }^{70}$ A more problematic issue related to the surviving sources, is whether there is any evidence for contact between Norway and the papacy in connection with the crusade in 1152.

The crusade bulls of Eugenius III circulated widely in Europe, ${ }^{71}$ but there is no record of any papal bulls or crusade preaching in the Norwegian domains. ${ }^{72}$ This does not mean that the crusade was not known here, as it was definitely known in neighbouring Denmark. ${ }^{73}$ There are some references to the crusade bulls of Eugenius

67 The eyewitness account was that of Fulcher of Chartres, who had participated in the First Crusade and later settled in the Latin kingdom, where he between 1101 and $c .1128$ wrote a chronicle about the First Crusade. For references to Fulcher and an overview of the sources to King Sigurd's crusade, see Halvdan Koht, "Kong Sigurd på Jorsal-ferd," Historisk Tidsskrift 5 (1924): 153-68, with a few more references in Svenungsen, "Norge og korstogene," 58-60, 65-8.

68 Morkinskinna ch. 95; Snorri Sturluson, Heimskringla: vol. 3, Haraldssona saga ch. 17; Islandske Annaler indtil 1578, ed. Gustav Storm, Christiania: Grøndahl \& Søns Bogtrykkeri, 1888.

69 Regarding the ideology of the Orkneyinga saga, see Peter Foote, "Observations on Orkneyinga Saga,” in St. Magnus Cathedral and Orkney's Twelfth Century Renaissance, ed. B.E. Crawford (Aberdeen: Aberdeen University Press, 1988), 192-207.

70 Generally, scholars agree that skaldic poems did not change considerably from time of composition to when they were written down, sometimes centuries later. The reason for this, is the strict metric rules of Norse poetry. Too many changes would ultimately lead to a collapse of meaning, see Bergsveinn Birgisson, "Inn i skaldens sinn. Kognitive, estetiske og historiske skatter i den norrøne skaldediktingen” (PhD thesis, University of Bergen, 2008). See also Chapter 4 (Bjørn Bandlien), 61-3.

71 Phillips, The Second Crusade, 37-79.

72 This is one of very few known letters from Eugenius III to Norwegian recipients, is his letter of confirmation to Munkeliv monastery in Bergen dated 7 January 1146, see DN vol. 12, 1. Very few papal letters or bulls sent to Norway during the Middle Ages are preserved, see Ludvik Holm-Olsen, Med fjærpenn og pergament. Vår skriftkultur i middelalderen (Oslo: Cappelen, 1990).

73 In 1146 a papal legate by the name of Hubaldus was in Denmark in connection with the Wendish crusade, while both Divina dispensatione (II) and the accompanying preaching letter of Bernard of Clairvaux were known. According to Janus Møller Jensen, Saxo’s chronicle clearly echoes these two sources, Jensen, "Denmark and the Holy War," 224; Jensen, "The Second Crusade and the Significance of Crusading,” 177. 
III in Denmark, where the Knytlinga saga mentions that "[a]bout this time Jerusalem was captured by the infidel and messages came from Pope Eugenius that men should take up the cross for a journey to Jerusalem to battle against the infidel." ${ }^{74}$ Even if the saga author mistook Edessa for Jerusalem, the reference is not without merit. According to Janus Møller Jensen, the saga implies "that the crusade to Outremer was preached in Denmark before the crusade was turned against the Wends."75 Considering the strong political and cultural contact between Norway and Denmark, it is hard to believe that news of the crusade did not cross over the sea and reach the Norwegians. $^{76}$

The closest we get to at least a faint hint of ecclesiastical authority, is the presence and participation in the crusade of the bishop of Orkney. Bishop William, known as "the old" (Old Norse hinn gamli, Latin senex), was, according to the Orkeyinga saga, bishop of Orkney for more than 66 years. He was an educated man who had studied in Paris, and he had been instrumental in the canonization of St Magnus of Orkney in $1136 .{ }^{77} \mathrm{He}$ was one of the senior figures of the crusade, even commanding one of the ships in the fleet. ${ }^{78}$ However, the bishop acted only as an interpreter and did not instigate the expedition as far as the sources are concerned. ${ }^{79}$ Nevertheless, to conclude ex silentio that the lack of surviving records for any papal bull proves the crusade was not preached in Norway, is to overlook important contacts between Norway and leading ecclesiastical institutions on the continent.

In the twelfth century there was extensive contact between Norway and the continent. Norwegian students travelled abroad to the emerging universities in France and England, later to Italy and Northern Germany. But the contact also included the houses of the new monastic orders, such as the Cistercians and Premonstratensians, which were international hubs for the spread of new ideas and reform. The importance of this stronger contact with the European continent is evident by the fact that all three successive archbishops of Nidaros in the second half of twelfth century,

74 Knytlinga Saga, 147.

75 Jensen, Crusading at the Edges of Europe, 178.

76 In the saga there is a reference to King Inge just prior to coming of the papal letter, see Knytlinga Saga, 142-3.

77 The saga refers to William as Parisklerkr (“clerk of Paris”), Orkneyinga Saga, ch. 85. For Nordic students abroad in the twelfth century, see Sverre Bagge, "Nordic Students at Foreign Universities," Scandinavian Journal of History 9 (1984): 1-29.

78 In the saga, there are at least three examples of his high status (besides his rank as a bishop). Firstly, he is mentioned right after Earl Rognvald in rank among those who commanded ships in the fleet. Secondly, the other leaders turn to him and ask for advice before the engagement with the Muslim ship. Thirdly, he is again mentioned second only to the earl at the arrival in Apulia on the return journey, see Orkneyinga Saga, chs 86, 87, 89.

79 The bishop's role might have been downplayed by the later saga author considering the saga's main perspective is that of the Earls of Orkney, not the church. 
Eystein (r. 1161-1188), Eirik (r. 1189-1205) and Thore (r. 1206-1214), had a connection to the learning centre St Victor in Paris. ${ }^{80}$ An intellectual culture emerged in Norway in the same period, where scholars like Theodoricus Monachus tried to link the history of Norway to the history of salvation - a history centred on Jerusalem. ${ }^{81}$

The stronger contact with the continent was not only marked by people travelling out of Norway, but also by people travelling into the country. New monastic orders established themselves in Norway during the twelfth century, such as the Cistercians and Premonstratensians, and around 1200, even one of the military orders, the Hospitallers (after the Hospital of St John of Jerusalem), established a house in the eastern parts of the country. ${ }^{82}$ The Cistercians were first. In 1145, Bishop Sigurd of Bergen (r. 1139-1159) visited Fountains Abbey in Yorkshire and afterwards invited the order to his diocese, resulting in the first Cistercian monastic foundation in Norway the following year at Lyse, near Bergen. ${ }^{83}$ A second monastery followed in 1147, this time at the isle Hovedøya in the Oslo fjord. Again, the founding was the result of a Norwegian initiative, and the monastery was filled with English monks. ${ }^{84}$ This time there was a royal connection also: the donation of Hovedøya to the Cistercians was confirmed in a letter by King Inge kryppill (Hunchback, r. 1136-1161). ${ }^{85}$ I will return later to this issue of royal connections with the crusade.

The coming of the Cistercians to Norway coincided with the preaching of the Second Crusade by the order's famous abbot, St Bernard of Clairvaux (1090-1153). ${ }^{86}$ Bernard was a keen promoter of the crusade, and his support was crucial for the expansion of the crusade into the Baltic region. Moreover, he had strong ties to important crusade institutions in Jerusalem, like the Templars. ${ }^{87}$

80 Bagge, "Nordic Students at Foreign Universities," 3-5.

81 Sverre Bagge, "Theodoricus Monachus: Clerical Historiography in Twelfth Century Norway," Scandinavian Journal of History 14 (1989): 117-123. For historiography and salvation history, see also the introduction to this volume, Chapter 1 (Kristin B. Aavitsland), 23.

82 For the Hospitallers at Varna (Værne), see Trond Svandal, Johannitterordenen: en ridderorden $i$ det norske middelaldersamfunnet (Oslo: Middelalderforum, 2006).

83 For the Cistercians in Norway, see Arne Odd Johnsen, De norske cistercienserklostre 1146-1264: Sett i europeisk sammenheng (Oslo - Bergen - Tromsø: Universitetsforlaget, 1977).

84 The monks came from the Cistercian abbey at Kirkstead, in Lincolnshire, see DN, vol. 17 B (tillæg), 241.

85 The letter itself is lost, but the Akershusregister of 1622 attests the existence of the letter ("Kong Inga hans breff om hegnadt paa stadenom, giffuet thill Huodøe closter . . ."), Akershusregisteret af 1622, ed. G. Tank, Den norske historiske Kildeskriftkommission, Kristiania: Grøndahl \& Søns boktryggeri, 1916.

86 For Bernard's preaching tour, see Phillips, The Second Crusade, 80-98.

87 Bernard had written a general rule for the Templars and praised them in his De laude novae militae (c.1130), see Philips 2007, The Second Crusade: 57, 73. 
During his preaching tour on the continent, Bernard wrote a letter to the English, which served as a blueprint for the preaching of the cross by the clergy. ${ }^{88}$ Christopher Tyerman argues that the Cistercians played a prominent role in the preaching and organising of the crusade in England. ${ }^{89}$ Considering that the first Cistercians in Norway were English monks, it is likely that they were well informed about the planned crusade.

\section{A Journey to Jerusalem}

In the Orkneyinga saga, the origin of Rongvald and Erling's expedition can be traced back to events at the royal court. In 1149, Earl Rognvald was invited by King Inge to his court in Bergen. This was an attempt by the king's advisors to bring the earl closer to Inge's faction during the increased tensions between the three brothers and co-rulers, Inge, Sigurd (r.1136-1155), and Eystein (r.1142-1157). ${ }^{90}$ At the same time, a man named Eindridi ungi (the Young) came to Bergen. He returned to Norway after many years of mercenary service in Constantinople. ${ }^{91}$ The saga mentions that Eindridi brought "much news" [morg tidendi] from the East, without specifying the content of that news any further.

We can only speculate what Eindridi actually told his listeners. It might have been news related to the failed crusade of the two kings Conrad III of Germany (r.1138-1152), and Louis VII of France (r.1137-1180). ${ }^{92}$ If he did not mention this defeat (which would seem unstrategic for recruitment), he might have told about the successful capture of Lisbon by crusaders from England and the Low Countries in $1147 .{ }^{93}$ Considering later events, it seems highly possible that Eindridi had ulterior motives for coming back home; but for whatever reason, the tantalizing and

88 Tyerman, England and the Crusades, 154-55.

89 However, as Tyerman points out, the political turmoil in England in the 1140s, were "hardly conducive to unequivocal royal or baronial support" for any crusade in the period, see Tyerman, England and the Crusades, 155.

90 Orkneyinga Saga, ch. 85.

91 For Eindridi's career in the Varangian Guard, see Blöndal, The Varangians of Byzantium, 50, 5253, 55-57, 61, 86, 217.

92 Eindridi might have seen Conrad and Louis, who travelled by way of Constantinople, see Phillips, The Second Crusade, 185-206.

93 The story of the siege was later written by one of the participants, a man named Raol, see $D e$ expugnatione Lyxobonensi: The Conquest of Lisbon, ed. and trans. C.W. David, New York: Columbia University Press, 2001. Eindridi might have heard about the siege from English Varangians. After the Norman conquest of 1066, many Anglo-Saxons travelled to Constantinople and by the later stages of the company's existence, it was dominated primarily by English and Slavic mercenaries, see Blöndal, The Varangians of Byzantium. 
powerful name of Jerusalem had been spoken. ${ }^{94}$ The result of Eindridi's speech was that several of the leading men in the king's circle agreed upon a journey to Jerusalem. This, however, was not the first connection between the earls of Orkney and Jerusalem. In the 1120s, Earl Hákon Pálsson (r.1105-1123) had undertaken a pilgrimage to both Rome and Jerusalem, possibly as penance for the killing of his fellow earl and co-ruler, St Magnus. ${ }^{95}$ Earl Rognvald, who was a nephew of St Magnus, was himself perhaps not all that unfamiliar with the idea of a crusade. As a young man, Rognvald had met another famous Norse crusader, namely King Sigurd jórsalafari, and it was also the latter who had made him earl and invested him with half of Orkney in $1129 .{ }^{96}$

In contrast to the earlier crusade of King Sigurd, the sources mention the names of several of those who participated in Earl Rognvald's crusade. ${ }^{97}$ This information gives us a better understanding of the social structures involved, which suggests that Norse crusades had perhaps more in common with their European counterparts than what earlier historians have espoused. Family and kinship played an important part in the organisation and financing of crusade expeditions, and some families were more inclined, at least in the early history of the crusades, to participate. ${ }^{98}$ John France underlines the importance of social bonds, which he labels as "patronage," meaning that if a lord took the cross, members of his household were probably obliged to participate as well. ${ }^{99}$ This was especially the case when the crusade had a royal initiative. ${ }^{100}$ The superiors could, however, also experience social pressure. During their conversation, Eindridi said to Earl Rognvald: "It seems very odd to me, Earl [. . .], that you don't

94 He might have been sent by the Byzantine Emperor to recruit Norse mercenaries, like Reidar sendimadr (Messenger) was later in the 1190s, see Sverris saga etter Cod. Am $3274^{\circ}$, ed. Gustav Indrebø, Kristiania: Den Norske historiske kildeskriftkommission, 1920; Blöndal, The Varangians of Byzantium, 155, claims the saga "hints fairly strongly" at this. For the career of Reidar sendimadr, see Pål B. Svenungsen, “Væring, bagler og pilegrim - Reidar Sendemanns liv og virke,” Historie 3 (2010): 22-30.

95 Orkneyinga Saga 1978, ch. 52.

96 Cf. Orkneyinga Saga, chs 61-2.

97 Most likely, several magnates participated in King Sigurd's crusade, but, except for the king, the only named participants are some of the Icelandic skalds in the king's retinue, even if not all of them had participated in person, and some based their accounts of the crusade on second-hand information. One of few known participants, was the Icelandic skald Aslak Hani (the Rooster), who during a later quarrel with King Sigurd, referred to the crusade, see Morkinskinna, ch. 77.

98 Jonathan Riley-Smith, The First Crusades, 1095-1131 (Cambridge: Cambridge University Press, 1997), 99, et passim.

99 John France, "Patronage and the Appeal of the First Crusade," in The First Crusade: Origins and Impact, ed. Jonathan Phillips (Manchester: Manchester University Press, 1997), 5-20.

100 The effect of royal patronage was evident at King Louis VII's elaborate cross-taking ceremony at Vézelay, which led many to follow his example, see Phillips, The Second Crusade, 103. As Tyerman argues, when the central objective of royal government was a crusade it "attracted large numbers from the political elite," see Tyerman, England and the Crusades, 67. 
want to go to the Holy Land yourself, but are content to listen to people's reports about it." He then continued to argue how expeditions to Jerusalem was associated with men of ability, such as the earl, and underlined that "it would bring you great respect if you were to mix with people from the noblest families." In the Orkeyinga saga, it is further mentioned that "many of the most respected men" expected Earl Rognvald to lead the crusade. ${ }^{101}$ A similar example of a group expecting their social superiors to lead a crusade is found in one of the accounts of King Sigurd's crusade. ${ }^{102}$

Both bonds of kinship and patronage played an important part in connection with the crusade of 1152. Several of the leading participants were related through kinship; according to the Orkneyinga saga, Earl Rognvald and Erling Ormsson were kinsmen. ${ }^{103}$ Similarly, another important landed man, Jon Peterson fotr (Foot), was Rognvald's brother-in-law. ${ }^{104}$ Besides kinship, other forms of social bonds, reflected in the hierarchical nature of medieval Norse society, were important in the organisation of the crusade. In the sources, two distinct networks appear on different levels. First, on a national level, there is an outline of a royal network centred around the court of King Inge, consisting mostly of magnates from Western Norway. ${ }^{105}$ Besides the earl, this included the already mentioned Erling Ormsson, who was from Etne in Hordaland, as well as Jon Petersson, who was from Sogn. Other important men were Aslak Erlendsson, from Hernar northwest of Bergen, ${ }^{106}$ and Guttorm Mjolukoll, from Hálogaland in the northern part of Norway. ${ }^{107}$

Second, at a regional level a local Orcadian network appears, centring on the earl's household and followers. In theory, crusading was a voluntary and devotional act, but people could be driven into taking the cross. ${ }^{108}$ Fear of one's lord combined with the hope of salvation made crusading so attractive to a fair crosssection of medieval society. The foremost member of the Orcadian network was the already mentioned bishop of Orkney, William, while some of the other named

101 "margir gaufgir men", Orkneyinga Saga 1978, ch. 85.

102 According to Snorri, returning crusaders, who had participated in Skopti Gomundsson's expedition, urged that one of the three brothers and co-rulers, Sigurd, Eystein and Olav, should lead an expedition eastwards. Snorri, however, is the only source to refer to this and in other sagas presents it as a royal initiative rooted in the personal motives and piety of King Sigurd, see Morkinskinna, ch. 60; Ågrip or Noregs kongesoger, trans. Gustav Indrebø, Oslo: Det norske samlaget, 1973; Fagrskinna: En norsk kongesaga, trans. J. Schreiner, Oslo: Fabritius, 1926.

103 Orkneyinga Saga, ch. 61.

104 Jon and Rognvald had previously been in conflict, and as part of a peace agreement, Jon had married Rognvald's sister, see Orkneyinga Saga, ch. 61.

105 On the social background of the magnates, see Gustav Storm, "Om lendermandsklassens talrighed i det 12- og 13. Arhundrede,” Historisk Tidsskrift 2, no. 4 (1884): 129-88.

106 Aslak is later mentioned as one of the men who participated in the killing of King Inge's brother and rival, King Sigurd munnr (Mouth).

107 Svenungsen, "Norge og korstogene," 93-4.

108 Riley-Smith, The First Crusades, 90. 
members were Magnus Havardsson, a member of one of the leading families in Orkney, and Svein Roaldsson, who was the Earl's cupbearer [skutelsvein]. ${ }^{109}$ The Orcadian network also consisted of the earl's skalds and other minor members of his household. ${ }^{110}$ This latter group might even have included some women in the earl's service. $^{111}$

Royal connections are not surprising to find, especially considering how dependent the early Norse crusade participation had hinged on royal support and participation. King Inge, who was described as a pious man and who was on good terms with the church, ${ }^{112}$ might have compensated financially for being physical unfit to take part in the expedition, hoping to receive some kind of spiritual reward in return. ${ }^{113}$ Despite the saga's silence regarding the extent of the king's involvement, King Inge did at least support the earl's expedition with a pair of longships. ${ }^{114}$ This was most certainly a welcome gift, as the cost of crusading was huge - it is estimated that participation required four times a knight's annual income $\mathrm{e}^{115}$ - and the participants had themselves agreed upon a two-year preparation period to build ships. ${ }^{116}$ Nothing is mentioned in the sources about the Norwegian clergy's involvement in the crusade, but leading ecclesiastics may very well have supported it. One

109 On his mother's side, Håvard descendent from Earl Paul Thorfinsson (d.1099), who was earl of Orkney until King Magnus Barefoot invaded the islands in 1098 and installed his son, Sigurd, as earl. 110 The four skalds in the earl's retinue was the Icelanders Torgeir Savakoll, Odde inn litli (Tiny), Torbjørn svarti (the Black), and Årmod. The saga also mentions several other important men from Orkney, among them Torkjell krókauga (the Crooked eyed), Grimkjell of Glettunes (Glaitness), Blån Torsteinsson, and Sigmund Ongul, a skald and relative of the powerful Orkney chieftain, Svein Åsleivsson. The saga also mentions a man called Audun rauði (the Red), a warrior who might have been in the service of Erling.

111 One of the rune carvings at Maeshowe, has been interpreted as referring to the woman's name Hlif, who further was the "the earl's cook" or "housekeeper” [matselja jarls], see Michael P. Barnes, ed. The Runic Inscriptions of Maeshowe, Orkney, Runrön (Uppsala: Institutionen för nordiska språk, Uppsala Universitet, 1994), 189 and Chapter 21 (Mikael Males), 456 and Fig. 21.1.

112 Although crippled after an incident in his early childhood, Inge was born in wedlock and the reformers increasing demand that kings should be of legitimate birth gave Inge an advantage over his brothers, see Knut Helle, Norge blir en stat 1130-1319, second ed. (Oslo: Fagbokforlaget, 1974), 47. The papal legate to Norway in 1152/1153, Cardinal Nicholas Breakspear (the later Pope Hadrian IV), clearly expressed his favour of Inge, referring him as "his son," see Johnsen 1945, Studier vedrørende kardinal Nicolaus Brekespears legasjon til Norden: 30-1.

113 In the early parts of the thirteenth century, new economic innovations introduced by Innocent III, meant that people who either sponsored someone to travel on a crusade in their place or supported the crusade economically, would be given parts or a full grant of the lucrative crusader indulgence.

114 Unfortunately, though, the gift would not benefit the crusade: While Earl Rognvald gave one ship to his kinsman and co-earl, Harald Maddasson, the other ship was shipwrecked on the return to Orkney, Orkneyinga Saga, ch. 85.

115 Riley-Smith, The First Crusades, 112.

116 Orkneyinga Saga, ch. 85. 
possible candidate in this regard is Eystein Erlendsson (d. 1188), who was King Inge's court chaplain and later became the second Archbishop of Nidaros. As already mentioned, he was educated in Paris and had strong ties to the reform movement and leading ecclesiastical institutions on the continent. Later he was to be instrumental in the incorporation of elements of crusading ideology in canon and secular law, enacted in defence of the reign of Erling skakki's son, King Magnus Erlingsson. ${ }^{117}$

\section{An Outline of Events}

Scandinavian pilgrims and crusaders travelling to Jerusalem could choose between several different routes. A popular route was the so-called Rómavegr (Roman way) which went by land through Germany, across the Alps, and into Italy. From Rome, pilgrims could then travel south to Bari where they could board a ship to the Holy Land. Another route was the Austrvegr (East way) which went eastwards by way of the many Russian rivers down to Constantinople. ${ }^{118}$ This route had been popular since the ninth and tenth century among Scandinavians seeking mercenary service in the Varangian Guard in Constantinople. ${ }^{119}$ Earl Rognvald chose a third route and followed in the footsteps of earlier Norse crusaders and took the southern route, the so-called Sudrvegr (South way). This was geographically the longest route and meant travelling around the Iberian Peninsula and into the Mediterranean, but it was the more efficient as it went by the sea.

The Orkneyinga saga mentions that the fleet first sailed south from Orkney to Scotland, then down the coast of Northumbria, before crossing over to France. According to the saga, the fleet then made its first stop at Narbonne [Narbón]. ${ }^{120}$ For obvious geographical reasons, the chronology of the saga must be wrong. Instead, the first stop was most likely in Galicia. ${ }^{121}$ The saga's description of the stay in Spain draws on parallels to the earlier crusade of King Sigurd, especially the

117 Archbishop Eystein was most likely the architect behind King Magnus's coronation oath and letter of privileges to the Norwegian Church, as well as the Caonenes nidrosiensis, see Norske middelalderdokumenter, ed. and trans. Sverre Bagge, et al., Bergen: Universitetsforlaget, 1973. For a modern biography of Eystein, see Erik Gunnes, Erkebiskop Øystein - Statsmann og kirkebygger (Oslo: Aschehoug, 1996).

118 Cf. Krijna N. Ciggaar, Western Travellers to Constantinople: The West and Byzantium, 962-1204, The Medieval Mediterranean (Leiden: Brill, 1996).

119 Blöndal, The Varangians of Byzantiu, 1-14.

120 Orkneyinga Saga, ch. 86.

121 Orkneyinga Saga, ch. 86. 
Norse crusaders' conflict with local Christians. ${ }^{122}$ After this, the fleet sailed down along the coast of Spain while looting in al-Andalus, which was known as "pagan Spain," and is a theme I will return to. After the fleet passed the Strait of Gibraltar [Niorfasund], Eindridi, along with six ships, parted company with the main fleet and sailed for Marseilles [Marseilar], from whence he travelled straight to Constantinople. ${ }^{123}$ It was probably right before or after Eindridi's departure, that the fleet made the aforementioned stop at Narbonne. Here they were welcomed by Viscountess Ermengarde [Ermingerpr] (r. 1134-1192), and stayed as guests at her court. ${ }^{124}$ Narbonne was a centre for the emerging courtly culture in Southern France and famous for its patronage of troubadours. ${ }^{125}$ Ermengarde's family had strong ties to the crusade movement: her ancestors had participated in the crusades to both Jerusalem and Iberia, and Ermengarde herself had been present at the siege of Almeria in $1148 .^{126}$

The visit to Narbonne proved instrumental in the transmission of new cultural impulses from the Continent to the northern periphery of the Latin West. The influence is evident in several poems composed by both the earl and several of his named skalds written directly after their stay at the court of Ermengarde. In fact, the viscountess is the centre of attention in several of these poems, praised for her beauty and grace, as "[my] clever sweetheart," "my golden-locked girl," or "the elegant Ermingerd."127 This should not be understood merely as the poetic expressions of lovesick Norse crusaders (despite the arduous sea voyage), but rather as an attempt to demonstrate their mastery of this new, courtly fashion to an audience back home. ${ }^{128}$

After the stay in Narbonne, the fleet sailed along the coast of North Africa [Serkland], before they made another stop near Sardinia [Sardinarey]. Not long after

122 In both accounts the contact between the Norse crusaders and the locals were initially peaceful, but when the Norsemen were denied access to local markets the conflict quickly escalated. Regarding King Sigurd, see Morkinskinna, ch. 61, while for Rognvald, see Orkneyinga Saga, ch. 86-7. A difference between the two stories, however, is that Rognvald was offered access to markets by the locals in exchange for driving off a group of castle-dwellers that had oppressed the countryside. Nevertheless, in both cases the saga authors seem uncomfortable with the fact that the crusaders attacked fellow Christians and hence use much space to justify the attacks.

123 Orkneyinga Saga, ch. 87.

124 Regarding Ermengarde's family and background, see Fredrick L. Cheyette, Ermengarde of Narbonne and the World of the Troubadours (Ithaca: Cornell University Press, 2001).

125 Cf. Jacqueline Callie, Medieval Narbonne: A City at the Heart of the Troubadour World (Aldershot: Ashgate, 2005).

126 One of her ancestors, Count Aimery I, had participated in the First Crusade, while her father, Count Aimery II, died while participating in the Reconquista in Iberia, see Cheyette, Ermengarde of Narbonne; Constable, "The Second Crusade," 243.

127 Orkneyinga Saga, ch. 86.

128 Interestingly enough, later Norse translations of French romances in the thirteenth century are marked by a tendency that the translator (often a cleric), left out the more erotic elements in the original version. 
this, the crusaders spotted and fought against a foreign ship, a so-called dromund. ${ }^{129}$ The ensuing battle is the climax in the saga's narrative. It was a fierce battle, but eventually the Norse crusaders were victorious, killing everyone on-board, except one man: the captain, whom they held for ransom. After this climax, the saga's narrative drops off. The accounts of both the stay in the Holy Land and in Constantinople are very brief compared with the earlier parts of the journey. ${ }^{130}$ This was perhaps related to the fact that when the Norse crusaders arrived in the Holy Land, the general crusade was long over. After visiting the holy sites, including bathing in the holy river of Jordan, the Norse crusaders started the journey back home. Their first stop homeward was a place called Imbolum, ${ }^{131}$ of which the saga relates about an episode of drunkenness that ended in tragedy. ${ }^{132}$ The fleet next reached Constantinople. Here they were reunited with their former co-crusader, Eindridi, but this relationship was rather strained.

Here, the saga author applies a common topos in the Norse literature, namely the motive of the good reception of the Northerners. Upon arrival, Earl Rognvald was greeted in person by "the chair-king", i.e. the Emperor Manuel Komnenos (r.1143-1180). The Emperor then presented Earl Rognvald with rich gifts, and tried to persuade him and the other Norsemen to stay and take service in the Byzantine army. ${ }^{133}$ His tactics, however, did not work and after staying the winter, the Norse crusaders travelled onward from Constantinople to Durazzo, where they crossed over to Apulia, and abandoned the ships for horses. ${ }^{134}$ After a brief visit to Rome, the crusaders followed the Rómavegr by land to Denmark and then continued on to Norway. According to the saga, the journey had taken three years.

129 Orkneyinga Saga, ch. 87-8. Regarding the dromund ship style, see John H. Pryor and Elisabeth M. Jeffreys, The Age of the $\triangle P O M \Omega N$ : The Byzantine Navy, ca 500-1204 (Leiden: Brill, 2006). 130 Orkneyinga Saga, ch. 87-8.

131 This might be a Norse misunderstanding of the Greek word embolon, meaning "market".

132 Jon Petersson fotr disappeared and was later found murdered by the city wall, see Orkneyinga Saga, ch. 88.

133 Orkneyinga Saga, ch. 89.

134 Richard Unger argues that there are two reasons to why the Norse crusaders did not travel back home by sea. First, because ship worms [teredo navalis], found in the warm water of the Mediterranean, damaged the northern ships so they became useless. Other northern crusaders, like King Richard I, experienced the same. Second, Unger argues that the Norse long ship lacked the technological advance to cross the strong currents of the Mediterranean and sail westwards back through Gibraltar, see Richard W. Unger, "The Northern Crusaders: The Logistics of English and Other Northern Crusader Fleets," in Logistics of Warfare in the Age of the Crusades. Proceedings of a Workshop held at the Centre for Medieval Studies, University of Sydney, 30 September to 4 October 2002, ed. John H. Pryor (Aldershot: Ashgate, 2006), 251-73. 


\section{An Economic Endeavour?}

The saga's brief account of the stay in the Holy Land compared to other parts of the journey, combined with references to the taking of "booty" and "plunder," and the fact that Norse crusaders usually stopped in Constantinople on their journeys, has led many historians to reject the idea that the expedition was a crusade. Instead, some have gone as far as calling it "a carefree Viking jaunt." 135 This assumption, however, rests on thin evidence. The belief that material and spiritual motives are mutually exclusive is a modern distinction which does not necessarily apply to medieval culture. ${ }^{136}$ Constantinople was attractive not only for its material wealth, but also for its spiritual authority. An often-neglected aspect is that before the sacking of 1204, Constantinople held one of the largest collections of relics and churches in all of Christendom. This included both relics and churches dedicated to St Olav, the patron saint of Norway. ${ }^{137}$

Still, the argument that material motives played an important role is difficult to completely reject. Indeed, for some participants, like Eindridi ungi, it seems to have been a leading factor for their participation in the crusade. ${ }^{138}$ Despite the church's desire to control the crusades from the start, the papacy could not prevent participants from adding their own motives and aspirations into the enterprise they were partaking in. ${ }^{139}$ The Clermont decree emphasized the desired state of mind of the crusader: participation should only be undertaken "for devotion alone, not to obtain honour or money." "Despite the church's efforts, it was unavoidable that the crusades became associated with certain secular ideals. Like all theatres of war, it became an arena for warriors (even the very pious among them) to demonstrate their courage and prowess. ${ }^{141}$

135 F.T. Wainwright, "The Golden Age and After," in The Northern Isles, ed. F.T. Wainwright (Edinburgh: Nelson, 1962), 192, quoted here after Jensen, "The Second Crusade and the Significance of Crusading,” 156, n. 4. See also Finnur Jónsson, “Røgnvald Jarls Jorsalfærd,” Historisk Tidskrift 8, no. 4 (1912-1913): 151-65.

136 For the many conflicting ideas in connection with the First Crusade, see Riley-Smith, The First Crusade and the Idea of Crusading.

137 From the early twelfth century, the Varangians in Constantinople had their own church, dedicated to the Virgin Mary and St Olav. The city also housed relics from St Olav, for instance his sword, which was kept in the Varangian church - while his helmet was in Antioch and his chain mail in Jerusalem. See Chapter 14 (Øystein Ekroll), 281.

138 A comparison with the Frist Crusade is the somewhat questionable motives of Bohemond of Taranto, see Riley-Smith, The First Crusades, 17-18.

139 It took almost a century before the concepts of the crusades were fully developed, see Tyerman, The Invention of the Crusades.

140 Urban II, The Councils of Urban II: Volume 1: Decreta Claromontensia, In Supplementum, ed. R. Sommerville, Annuarium Historiae Concilioruin, Internationale Zeitschrift für Konziliengeschichtsforschung, Adolf M. Hakkert: Amsterdam, 1972.

141 Richard W. Kaeuper, Holy Warriors: The Religious Ideology of Chivalry (Philadelphia: University of Pennsylvania Press, 2009); Cheyette, Ermengarde of Narbonne. During the twelfth and thirteenth 
One of the main reasons why the crusades became such an instant success across Europe was that it struck a chord within the warrior aristocracy. ${ }^{142}$ The idea of the crusades was not only an innovative concept within the theology of the church, but it also fulfilled a spiritual need within lay circles. Historians like Jonathan Riley-Smith and Marcus Bull have emphasised the centrality of Jerusalem in the religious consciousness of the Latin West, especially within lay circles, regarding the origin of the First Crusade. ${ }^{143}$ In a much quoted passage, the aforementioned Guibert of Nogent praised how, "God has established holy wars in our day, so that the order of knights and their followers [. . .] can find a new way of attaining salvation." 144 The crusades represented a new alternative for pious laymen, whereby they could obtain salvation without entering a monastery or laying down the sword. ${ }^{145}$ As one historian described the First Crusade, it was "a military monastery on the move."146

This, however, brings us to the issue of plunder. Plunder is mentioned several times in connection with both King Sigurd's crusade and the later crusade of Earl Rognvald. ${ }^{147}$ For example, the saga mentions for Earl Rognvald's crusade that the Norse crusaders gained plenty of plunder after the battle with the dromund. This reference would immediately seem like a violation of the Clermont decree's emphasis on "devotion alone," however these riches were not brought back to Scandinavia. According to the saga, after the battle, the Norse crusaders sailed south, "to the land of the Saracens" [Serklandi], ${ }^{148}$ where they made a truce with the townspeople and traded with them, "selling them silver and other valuables." "Th9 bles gained as booty would, as the saga suggests, be used to buy necessary supplies in order to sustain the fleet.

century it also became incorporated into ideals of kingship, see M. Cecilia Gaposchkin, The Making of Saint Louis. Kingship, Sanctity, and Crusade in the Later Middle Ages (Ithaca - London: Cornell University Press, 2008).

142 Bull, Knightly Piety and the Lay Response.

143 Riley-Smith, The First Crusade and the Idea of Crusading; H.E.J. Cowdrey, "Pope Urban II and the Idea of Crusade," Studi medievali 3rd Ser. 36 (1995); Bull, Knightly Piety and the Lay Response.

144 Nogent, The Deeds of the Franks Franks, 28.

145 Such a view is present in Ralph of Caen's Gesta Tancredi (c.1112-1130), a biography of Tancred, who was one of the leaders of the First Crusade and later became prince of Galilee, and regent of Antioch. According to Ralph, Tancred had, prior to joining the crusade, thought about entering a monastery, but then saw the crusades as a suitable alternative, see Ralph of Caen, Gesta Tancredi of Ralph of Caen: A History of the Normans on the First Crusade, ed. and trans. B.S. Bachrach and D.S. Bachrach, Farnham: Ashgate, 2010.

146 Riley-Smith, The First Crusade and the Idea of Crusading, 84.

147 For a more detailed discussion, see Svenungsen, "Norge og korstogene," 86-8.

148 The reference to Serklandi would indicate that that this place perhaps was a port in Northern Africa.

149 “. . . ok ættu vid pa kaup ok selldu peim [siilfr ok annat fee,” Orkneyinga Saga, ch. 88. 
Similar references to plunder and booty in connection with crusades are found in both Norse and Latin narratives, all the way back to the First Crusade. ${ }^{150}$ This might seem like a contradiction, but it should be remembered that any attempt to make a clear distinction between material and spiritual motives regarding medieval people, especially crusaders, easily becomes an anachronistic exercise. The dichotomy between material and spiritual is a modern construct; God could grant crusaders victory in battle as a sign of their right intention and state of mind, as well as reward them with the material spoils of war. ${ }^{151}$ In fact, at times even leading ecclesiastics used this profit motive to promote crusades in different parts of Europe. ${ }^{152}$

The many references to material gain have been used by some as an argument to denounce the crusades as mere profit-motivated enterprises, where religion acted as only a smoke screen for the greed and territorial ambitions of the western knights, especially the younger sons of the aristocracy left landless by the laws of primogenitur in Europe. ${ }^{153}$ This profit myth, according to Jonathan Riley-Smith, always rested on insufficient evidence ${ }^{154}$ and is rejected in most modern studies. ${ }^{155}$ Instead, consensus has shifted to an understanding that the cost of crusading far exceeded the profits ever gained. ${ }^{156}$ An issue often neglected in connection with references to plunder and booty during crusades is the challenges concerning provision. Few, if any, medieval armies were able to forage in advance. This made provision especially difficult when traveling through hostile territories. Plunder was at times the only way to sustain an army. This problematic issue, however, could at times lead crusaders into conflict with other Christians, as King Sigurd experienced with local Christians in Spain. ${ }^{157}$ Returning to the example above, the saga mentions how Earl Rognvald and the Norse crusaders traded "silver and other valuables," but it does not mention what they got in return - probably food and provisions.

150 Albert of Aachen referrer to crusaders taking booty and plunder, even before they reached Constantinople, see Albert of Aachen, Historia Ierosolimitana, 18-19, 24-25, 32-33, 52-53, 64-65, 74-75, 76-77, 82-83, et passim.

151 This was a view shared by several chroniclers after the crusaders victory over the Egyptian counter-invasion force a month after the capture of Jerusalem, see Riley-Smith, The First Crusades, 20. 152 In 1148, the bishops of Toldeo and Leon not only offered the crusaders spiritual blessings, but also the prospect of Moorish gold if the former proved insufficient, see Constable, "The Second Crusade as seen by Contemporaries," 231.

153 For such historiographical interpretations, see references in Housley, Contesting the Crusades.

154 Riley-Smith, The First Crusades, 19-22.

155 For myths connected to the crusades, see Alfred J. Andrea and Andrew Holt, eds., Seven Myths of the Crusades (Cambridge: Hackett Pub Co., 2015).

156 According to historian Peter Spufford, the crusades drained Europe of silver, see Peter Spufford, Money and its Use in Medieval Europe (Cambridge: Cambridge University Press, 1988), 74-106.

157 Morkinskinna, ch. 61. 


\section{Crusade or Pilgrimage?}

So far, I have tried to nuance the materialistic interpretation of the motives behind Earl Rognvald and Erling's expedition, but what about the presence of religious and ideological motives? One of the strongest, yet surprisingly often overlooked indications of the expedition's inherent religious character, is its destination. With the exception of Eindridi and his companions, ${ }^{158}$ the desired destination for the majority of the participants was Jerusalem, the pilgrim and crusade destination par excellence throughout the Middle Ages. ${ }^{159}$ A direct reference to a specific holy site is found in one of the earl's stanzas. In the poem, Rognvald tells how the sweet words of Ermingarde would echo in his ears, "enjoining us to journey by water to Jordan."160 The river Jordan, where Christ had been baptized, was one of the most popular sites to visit by Norse pilgrims and crusaders while in the Holy Land. ${ }^{161}$ If we accept the underlying religious motives, as expressed by the desired destination, this leads to further questions of the expedition's religious character. Is it possible to differentiate between the two most popular forms of devotional journeys to Jerusalem in the twelfth century, namely whether the expedition was a pilgrimage or a crusade?

In the Orkneyinga saga, there are several examples of what, in accordance with Purkis' distinction, can be labelled as an active military role, while the saga narrative also places the fighting within a clear religious context. Many of the participants aboard the Norse fleet were obviously heavily armed, as is clear from the military engagements, yet all of the saga accounts further define the enemies encountered according to their religious affiliation. ${ }^{162}$ In the Orkneyinga saga's narrative of the engagement with the big "Saracen ship" [dromundinum voru Saraceni], the so-called dromund, the enemy is first referred to as "Mohammed's heretics" [Maumets villumenn], and the saga author further remarks that "there were many blámenn and they offered the hardest resistance."163 In one stanza, Earl Rognvald

158 Still, even Eindridi only referred to Jerusalem [Iorsalaheim] in the saga's account, see Orkneyinga Saga, ch. 85.

159 For the centrality of the Holy Sepulchre and Jerusalem in medieval Christianity, see Morris, The Sepulchre of Christ.

160 "Orp skal Ermingerpar itr drengr muna lengi; brupr vill rauck, at ripim ranheim til Iordanar", Orkneyinga Saga, ch. 86.

161 The saga narratives of the pilgrimage and crusade of Harald harðráða and Sigurd jórsalafari mentions visits to and baths in the Jordan. It is also included in abbot Nikulás' travel guide, see Wilkinson, Hill, and Ryan, Jerusalem Pilgrimage, 215-19. See also Chapter 11 (Denys Pringle), 208 and Chapter 21 (Mikael Males), 460.

162 All the sagas accounts underline how the fighting was done against "heathens," i.e. Muslims, see Orkneyinga Saga, ch. 86-8; Morkinskinna, ch. 95; Snorri Sturluson, Heimskringla, vol. 3, Haraldssona saga ch. 17.

163 "Par var mart blámanna, ok veittu peir ina hǫrðustu móttǫku,” Orkneyinga Saga, ch. 88. 
also refers to the enemy as blamanna. ${ }^{164}$ The Norse term blámaðr, which directly translates as "blue man," is a somewhat ambivalent term with shifting meaning according to context; it could refer to different kinds of people Scandinavians encountered beyond the Mediterranean, more specifically to Ethiopians, Moors, and other foreign peoples (ethnic), but it also refers generally to Muslims (religious). ${ }^{165}$

There are no references to attempts at forced conversion of Muslim captives in the Orkeyinga saga. Instead, all enemies are killed without mercy with the exception of the ship's captain, who is captured alive. He is no blámaðr, but described as a "nobleman from Serkland." 166 Even though the crusaders fail to get a ransom for the man, he is not killed. In a scene which Robert Cole describes as "reminiscent of the chivalrous relationship of Saladin and Richard the Lionheart," he is let free and expresses his gratitude to the crusaders. ${ }^{167}$ Here the chivalrous elements are more evident than the religious ones. In contrast, the Morkinskinna mentions several incidents during the earlier crusade of King Sigurd, in which captive Muslims were given the choice between conversion and death. This happened, for example, after the Norse crusaders had taken a castle near the modern Portuguese town of Sintra [Sintré]. According to Morkinskinna, King Sigurd gave a speech resonating with Bernard of Clairvaux's rhetoric regarding the Wendish crusade, in which fighting the heathens was encouraged until "they shall be either converted or deleted." "68 In his address to captured Muslims, King Sigurd told captured Muslims "if you will accept the faith, I will spare your lives, although you deserve to die." 169 They all refused to convert and hence were killed. In both these cases, the Norse travellers did not take a passive role, but actively engaged the "enemies of Christ" in warfare. If the expedition was seen as a pilgrimage by either the participants or other contemporaries, it was definitely an armed one.

Despite the religious nature of the fighting, the later saga authors had a problem. By the time the Norse crusaders arrived in the Holy Land, the general crusade was long since over. Internal tension in the Latin kingdom in the early 1150s halted any crusading activity towards external enemies. ${ }^{170}$ This lack of a general crusade to participate in perhaps explains the strong emphasis in the sagas on the battles

164 Orkneyinga Saga, ch. 88.

165 Richard Cole, "Racial Thinking in Old Norse Literature: The Case of the Blámaðr," Saga-Book 39 (2015): 21-40; John Lindow, "Supernatural Others and Ethnic Others: A Millenium of World View," Scandinavian Studies 67, no. 1 (1995): 8-31.

166 “Qðlingr af Serklandi,” Orkneyinga Saga 1978: ch. 88.

167 Cole 2015, "Racial Thinking," 27.

168 Here quoted after, Christiansen, The Northern Crusades, 53.

169 “. . . ef per vilit við trv taca. pa mon ec gefa yðr lif. pott pat veri macligra at per verit drepnir," Morkinskinna, ch. 61.

170 A brief civil war was fought between mother and son, Queen Melisende and King Baldwin III, in 1152, as the latter wanted to be the sole ruler of the Latin kingdom, see Hans Eberhard Mayer, "Studies in the History of Queen Melisende of Jerusalem," Dumbarton Oaks Papers 26 (1972): 95-182. 
fought against Muslims in or near Spain, which parallels the earlier crusade of King Sigurd. ${ }^{171}$ But fighting Muslims in Iberia was not just a "second best" option, in fact, by the mid-1100s it was merely crusading in another arena. As mentioned above, in the 1140s Pope Eugenius III officially raised the status of the military campaigns in Iberia and the Baltic to the same level as the crusades towards the Holy Land. ${ }^{172}$ At least some contemporaries, like the German chronicler Helmold of Bosau (d. c.1177), saw these three campaign destination as forming part of a universal enterprise. ${ }^{173}$ Indeed, a more coherent crusade movement was beginning to take shape. The Iberian crusades seem to have attracted many Northern European crusaders. In 1147, crusaders from England, the Rhineland, and the Low Countries had participated in the siege and conquest of Lisbon. ${ }^{174}$ The contact between Iberia and Scandinavia was also getting stronger, ultimately culminating in several marriage alliances in the course of the thirteenth century. ${ }^{175}$ In fact, by the mid-twelfth century, it had become almost a common feature for Northern European crusaders travelling to Jerusalem to participate in crusading-related activities in Iberia, which represented minor engagements in the larger process of the Reconquista. ${ }^{176}$ Besides these military elements, there are other more identifiable signs that indicate how contemporaries, including the participants themselves, saw and understood these expeditions as crusades.

171 For King Sigurd's raid on the Balearic Islands during his crusade, see Doxey 1996, "Norwegian Crusaders and the Balearic Islands:" 139-60.

172 Jonathan Phillips, "Saint Bernard of Clairvaux, the Low Countries and the Lisbon Letter of the Second Crusade," Journal of Ecclesiastical History 48 (1997): 485-497.

173 Helmold of Bosau, Chronica Sclavorum, ed. Johann Martin Lappenberg and G.H. Pertz, Hannover: Impensis bibliopolii Hahniani, 1868. See also Constable, "The Second Crusade as seen by Contemporaries," 223.

174 English crusaders had previously participated in a failed siege of Lisbon in 1140, see De expugnatione Lyxobonensi.

175 This contact led to several interesting marriage arrangements between Iberian and Scandinavian royal houses, such as the marriage between King Valdemar Valdemar II and Berengaria of Portugal (1214) and Kristin, the daughter of the Norwegian King Haakon Haakonsson, and a brother of Alfonso X of Castile in 1258. For the connections between Denmark and Iberia, see Jensen, Crusading at the Edges of Europe. For Norway, see Svenungsen, "Norge og korstogene," 79-80, 195-202 and Chapter 23 (Jørn Øyrehagen Sunde), 516.

176 Joseph F. O'Callaghan, Reconquest and Crusade in Medieval Spain (Philadelphia: University of Pennsylvania Press, 2004), 31-2, who distinguishes between the Reconquista, which was a continual process that despite shorter or longer periods of truces and armistices had an overriding goal of Christian re-conquest, and crusades, which refers to an event or a specific campaign resulting from a proclamation by the pope, a council, a legate or a bishop who granted remission of sins to the participants. 


\section{Crusader and Pilgrim Insignias}

There are indications in the sources that Earl Rognvald had indeed taken the cross. According to the Orkeyinga saga, the earl announced his intentions to go on a crusade to his followers and to Bishop William during the Christmas celebrations. ${ }^{177}$ Feasts like Christmas and Easter, and also the two feast days for the Invention of the Cross (3 May), and the Exaltation of the Cross (September 14), were very often associated with cross taking ceremonies, because these feasts were so closely associated with Jerusalem and the Holy Cross. ${ }^{178}$ In France, King Louis VII had first announced his intentions to go on a crusade to his Christmas court at Bourges in 1145. ${ }^{179}$ Likewise, in connection with the later Third Crusade, the news of the fall of Jerusalem reached the Christmas court of the Danish king Knud VI (r.1182-1202), and the tidings led several important Danish magnates to spontaneously take the cross. ${ }^{180}$ But there are also references in Orkneyinga saga to crusader insignias. During the stay in the Holy Land, the Norse crusaders visited the holy places and, like other Scandinavian crusaders and pilgrims, this included a bath in the holy river of Jordan. After he rose from the water, the earl composed a poem. Here he mentioned "[a] cross on this bard's breast, on his back a palm branch." ${ }^{181}$ Both the cross and the palm were well-known pilgrim and crusader insignias, but the symbol of the cross, as by the second half of the twelfth century, was beginning to be more closely associated with crusaders, who were knowns as a crucesignati (cross bearers) ${ }^{182}$ Cross insignias are also found in Orcadian context outside the saga narrative.

At some time during the Middle Ages the Neolithic tomb of Maeshowe on the mainland in Orkney was broken into. ${ }^{183}$ The intruders left their mark in the form of graffiti, including runic inscription and several crosses. ${ }^{184}$ Michael Barnes dates the

177 Orkneyinga Saga, ch. 85.

178 Beverly M. Kenzle, "Preaching the Cross: Liturgy and Crusade Propaganda," Medieval Sermon Studies 53 (2009): 11-32.

179 Phillips, The Second Crusade, 62-6.

180 Historia de profectione Danorum in Hierosolymam, ed. 2007 M.C. Geertz, Scriptores minores historiæ Danicæ medii ævi, II, Copenhagen: Selskabet for udgivelse af kilder til dansk historie, 1922, 457-92. This Danish crusade is the topic of the subsequent Chapter 7 (Ane L. Bysted), 132-9.

181 Orkneyinga Saga, ch. 87.

182 Michael Markowski, “Crucesignatus: Its Origin and Early Usage," Journal of Medieval History 30, no. 1 (1984): 61-82; Giles Constable, "Jerusalem and the Sign of the Cross (with particular references to the cross of pilgrimage and crusading in the twelfth century)," in Jerusalem: Its Sanctity and Centrality to Judaism, Christianity, and Islam, ed. R.I. Levine (New York: Continuum International Publishing Group, 1999), 371-81.

183 Cf. Chapter 21 (Mikael Males), 456-61.

184 One of those who carved a cross identified himself, "Benedikt gerði kross Penna” (despite that there is no cross directly near the inscription), see Barnes, The Runic Inscriptions of Maeshowe, 170. 
inscriptions to between 1125 and $1175 .{ }^{185}$ This means the runes are possibly connected to events recorded in the Orkneyinga saga, where it is stated that the crusaders spent the first winter in Orkney. ${ }^{186}$ The geographical connection to Jerusalem is not only evident in the carvings of crosses, but also in several references in the inscriptions to "Jerusalem travellers" or "Jerusalem men."187 The carvings refer to named individuals, some of which may be leading participants in the crusade, but no certain identification is possible. ${ }^{188}$ The carvings, if made by the crusaders, are the closest we get to a glimpse into the mind-set of the participants. Furthermore, we find a clear religious understanding of the journey in some of the skaldic poetry associated with the participants, and in one stanza, Earl Rognvald sets forth the idea of the journey as a divine trial and the outcome of the battle against the Muslim dromund is an expression of "the will of God." ${ }^{\prime 89}$ His choice of wording may echo the First Crusaders battle cry Deus vult, "God wills it!”,190

\section{Bringing Jerusalem Back Home}

The continued involvement in the crusades to Jerusalem in the twelfth century affected the conception of the city in both Europe and Scandinavia. During the eleventh century, the three symbols of the cross, Christ, and Jerusalem became closely associated with each other in a way Giles Constable argues brought "together the earthly and heavenly Jerusalems." "191 The crusader spirituality of the twelfth century did, in many ways, represent a further extension of this idea: the crusader was not only a "soldier of Christ" [miles Christi], he (or she) was also "signed with the cross" [crucesignatus], and desired to go to the Holy Sepulchre in Jerusalem to venerate. Many kinds of religious and cultural impulses were transmitted through participation in the crusades. As the visit to Narbonne demonstrated, direct contact with cultural centres on the continent led to the transmission of new impulses, such as the

185 Barnes, The Runic Inscriptions of Maeshowe, Orkney. See also Runes: A Handbook (Woodbridge: Boydell Press, 2012).

186 Orkneyinga Saga, chs 85-6.

187 “Jorsalamenn brutu haug Penn,” Barnes 1994, The Runic Inscriptions of Maeshowe, 40.

188 Some scholars suggest that the names Erlingr and Einðriðr are mentioned in some of the inscriptions. If so, the association to Erling skakki and Eindridi ungi is close at hand. However, these interpretations are debated among scholars, see Barnes, The Runic Inscriptions of Maeshowe, 189.

189 "pvi hefir alldar gud valldit”, Orkneyinga Saga, ch. 88.

190 Bernard Hamilton, "'God Wills It': Signs of Divine Approval in the Crusade Movement," in Signs, Wonders, Miracles: Representations of Divine Power in the Life of the Church, ed. K. Cooper and J. Gregory (Woodbridge: The Boydell Press, 2005), 88-98.

191 Constable, "Jerusalem and the Sign of the Cross," 381. 
emerging courtly culture, that was absorbed and given a Norse expression. ${ }^{192}$ This indicates a wish within the Norse elite to prove they shared the same taste and norms as their European counterparts, and the same was also apparent in their ideas of Jerusalem. While the holiness and centrality of Jerusalem attracted Norse pilgrims and other far-travellers for centuries, the participation in the crusades in the twelfth century resulted in - or coincided with - an emerging desire to bring back a piece of the city's holiness.

The idea of a translation (translatio) of Jerusalem was common in medieval Europe. ${ }^{193}$ Translations could take on different forms and occur by either importing relics associated with Jerusalem, especially material substances connected to the life and passion of Christ, or by imitating architectural structures found in the Holy Land, especially the Holy Sepulchre. ${ }^{194}$ The translation of Jerusalem in Scandinavia was associated with both of these types. The transfer of relics is found in connection with the crusade of King Sigurd, who brought a relic of the Holy Cross to Norway, where it was later joined by another Jerusalem relic, the fingrgullit: a gold ring containing drops of the Holy Blood of Christ. ${ }^{195}$

In the twelfth and thirteenth centuries, many round churches were built across Europe. Several of these were associated with returning crusaders or crusade institutions, like the Hospitallers and the Templars. ${ }^{196}$ In this, as in most things, crusaders further developed previously established traditions, as returning pilgrims had already established similar round churches in the eleventh century. ${ }^{197}$ This phenomenon also occurred in Eastern Scandinavia, where several round churches were built, for instance at Bornholm and around the Baltic Sea. ${ }^{198}$ The Norse community was no different. In the twelfth century, at least three round churches were

192 Such as the introduction and appropriation of the new idea of hoeverska (courtly manners) into Norse elite culture, first encountered by Norse crusader during the visit to the court of Ermengarde in the southern parts of France.

193 Morris, The Sepulchre of Christ, 219-53; and Chapter 3 (Eivor Andersen Oftestad), 49-55.

194 Cf. Chapter 8 (Lukas Raupp), 140-65 Chapter 9 (Lena Liepe), 166-87, and Chapter 14 (Ekroll), 270-98. See also Kristin B. Aavitsland, "Defending Jerusalem: Visualizations of a Christian Identity in Medieval Scandinavia,” in Visual Constructs of Jerusalem, ed. Bianca Kühnel, et al. (Turnhout: Brepols, 2014), 125-28.

195 For the year 1165, Icelandic annals mention that "Blód várs herra Jesv Christi kom til Nidarós", Islandske Annaler: 1888, 117. For the relic of the Holy Cross, see Chapter 8 (Lukas Raupp), 140-66.

196 Morris, The Sepulchre of Christ, 230-45. See also Øystein Ekroll, "The Octagonal Shrine Chapel of St Olav at Nidaros Cathedral: An Investigation of its Fabric, Architecture and International Context" (PhD Thesis, NTNU, 2015), 319-329.

197 Housley, Fighting for the Cross, 280.

198 These churches did most likely serve several different functions, see Jes Wienberg, "Fæstninger, magasiner og symboler - Østersøens flertydige kirker,” META - Medeltidsarkäologisk tidskrift 4 (2000): 26-58. See Chapter 16 (Kersti Markus), 324-39 for round churches in Vestgötaland, Sweden. 





built in different parts of the Norwegian realm, such as Orkney (Fig. 6.2), Tønsberg and Nidaros, linked to either pilgrims, crusaders, or crusade institutions. ${ }^{199}$

The largest circular church in the whole of Scandinavia was the Premonstratensian church of St Olav in Tønsberg, in south-eastern Norway. ${ }^{200}$ It was most likely built in the second half of the twelfth century (before 1207), but its commissioner is not known. ${ }^{201}$ Several candidates, both Norwegian and Danish, have been suggested, including Erling skakki and his son King Magnus, who both had strong ties to Tønsberg. ${ }^{202}$ Perhaps the building of this church was part of legitimation strategy for the new royal lineage, referring to Erling's crusade participation.

\section{The Aftermath}

Generally, crusades had a very high mortality rate, and Norse crusades were no exception. It seems that a substantial part of Norse crusade armies perished due to the many hardships underway, like battles, diseases, or the more infamous Norse crusader-death of "alcohol-related incidents." ${ }^{203}$ Some of the participants might have chosen to stay behind in Constantinople, like Eindridi ungi, to enlist as mercenaries in the famous Varangian Guard. For those who survived the crusade, this was potentially a career-changing experience - for better or worse. The First Crusade was a success, and the returning crusaders became celebrities all over Europe. Later generations of crusaders, however, often received a lukewarm welcome at home. The failure of the Second Crusade resulted in the criticism of

199 The round church at Orphir is often associated with Earl Hákon Pálsson, who probably built it as a commemoration of his pilgrimage to Rome and Jerusalem in the 1120s, as penance for his involvement in the murder of St Magnus, see Aavitsland, "Defending Jerusalem,” 126.

200 The church is today preserved only as a ruin, see Øyvind Lunde, "Premonstratensernes kloster i Tunsberg - kirken og klosteranlegget," in Seminaret "kloster og by" 11.-13.november 1992. Omkring Olavsklosteret, premonstratenseserordenen og klostervesenet i middelalderen, ed. J.E.G. Eriksson and K. Schei (Tønsberg: Tønsberg bibliotek og Riksantikvaren, Utgravnings-kontoret for Tønsberg, 1993), 23-37. See also fig. 7.1, 132.

201 The ante date of the church is 1207, since the Croizer-King, Erling steinveggr (Stone wall), was buried in the wall of the church at this date.

202 Erling and Magnus stayed in Tønsberg for longer periods during the 1160s and 1170s. For other possible candidates, see Lunde, "Premonstratensernes kloster i Tunsberg," 23-37; Arne Odd Johnsen, Tønsberg gjennom tidene (Oslo: Gyldendal, 1971), 60-1.

203 In connection with Rongvald's crusade, we find examples of crusades dying of diseases, as Torbjørn svarti at Acre, or more violently, as Jon fotr at Imbolum. The latter, however, is not the only alcohol-related death involving Norse crusaders. According to William of Malmesbury, many of King Sigurd's men died suddenly during the stay in Constantinople. William then goes on to tell a fantastic tale, of how the king, by dissecting a dead man and conduction an experiment with a pig's liver, concluded that the deaths were caused by the drinking of undiluted wine, see William of Malmesbury, The History of the English Kings: II:V, ch. 410. 
everyone involved. The crusaders were blamed the most, as their sins were seen as the main cause for the campaign's failure, but not even Bernard of Clairvaux could escape criticism. ${ }^{204}$ In the aftermath of the Second Crusade, enthusiasm for crusading dropped to a new low and did not recover until the loss of Jerusalem in $1187 .^{205}$

In contrast, Earl Rognvald and his men received a hero's welcome upon their return to Norway. One generation earlier, King Sigurd had been honoured with the epithet jórsalafari, the Norse equivalent of the Latin jerosolimitani, an honorary title bestowed upon the first generation of crusaders. ${ }^{206}$ This welcome, however, does not seem to have been the case for later Norse crusaders; nevertheless, according to the Orkeneyinga saga, the journey still became "famous" and "everyone who made it was considered all the greater."207 The Orkneyinga saga only mentions a collective honour being bestowed upon the crusaders, but Snorri explicitly singles out Erling, who was "considered a much greater man" after the crusade. ${ }^{208}$ During the battle against the Muslim dromund, Erling received the blow to his neck that earned him the nickname of skakki ("Wry-neck").

At an actor level, the aftermath of the crusade in the mid-1150s proved very different for the two main leaders, respectively "the Saint" and "the Wry-neck." Upon his return to Orkney, Earl Rognvald found his domains in a state of political turmoil. For the remainder of his life he struggled to regain power over the earldom, before he was killed in a minor skirmish three years later. ${ }^{209}$ According to the Orkeyinga saga miracles were soon reported at his grave in the yet unfinished St Magnus Cathedral at Kirkwall (Fig. 6.1), which Rognvald had started building in $1137 .{ }^{210}$ According to Icelandic sources, Bishop Bjarni Kolbeinsson Skald (1188-1223), had Earl Rognvald canonized in 1192. ${ }^{211}$ Allegedly, the canonization was done with permission from Pope Celestine III (r.1191-1198), but no existing records can confirm this. Even if he did not live to benefit politically from his crusader status, it is more than likely that Rognvald's participation in the crusade, along with his kinship with St Magnus, the patron of Orkney, ${ }^{212}$ proved instrumental for his later canonization. ${ }^{213}$

204 Phillips, The Second Crusade, 269-79.

205 Philips, The Second Crusade, 269-79.

206 Housley, Fighting for the Cross, 270-2.

207 "Ok varp pessi ferp in fregsta; ok pottu peir allir myklu meira hattar men sipann”, Orkneyinga Saga, ch. 89.

208 "Pótti Erlingr nú miklu meiri maðr," Snorri Sturluson, Heimskringla: vol. 3, Haraldssona saga ch. 17 .

209 Orkneyinga Saga, chs 103-4.

210 Orkneyinga Saga, ch. 104.

211 Orkneyinga Saga, ch. 104; Islandske Annaler 1888: 120, 80, 324.

212 The former earl, St Magnus Erlendsson (d. 1115), was Rognvald's maternal uncle.

213 As was the case with another former crusader, King Louis IX of France, see Gaposchkin, The Making of Saint Louis. 


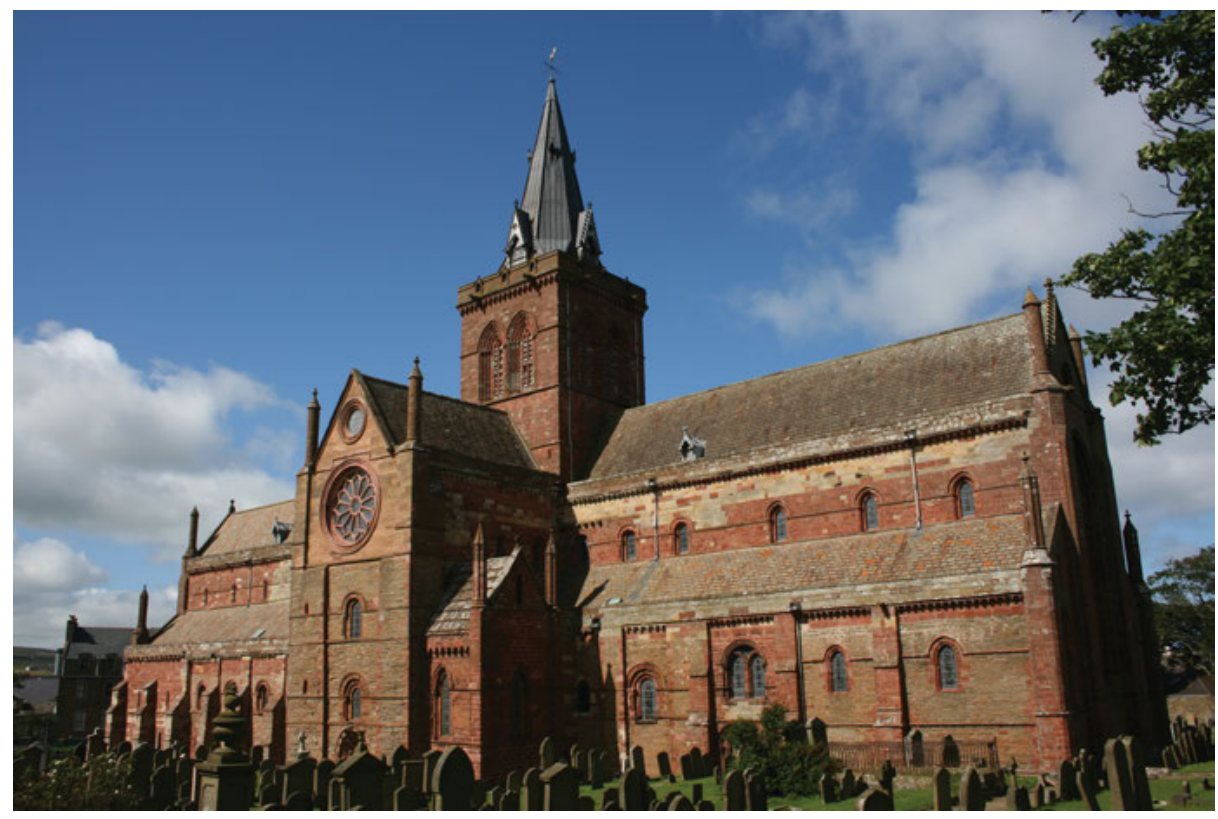

Fig. 6.2: Orkney, Kirkwall. St Magnus Cathedral, initiated 1137 by St Rognvald Kali Kolsson, earl of Orkney.

For other participants, the crusade had a more secular outcome, and no one benefitted more in this regard than Erling skakki. Not only did the crusader status prove vital in launching Erling's own political career, ${ }^{214}$ but it also laid the foundation for his son Magnus's later kingship. ${ }^{215}$ This was made possible by Erling's political manoeuvring, especially through the alliance with the Church. By granting the Church a wide range of privileges, the new dynasty got legitimacy in return. Because of this, King Magnus, Erling's son, received unction and coronation, the first such ceremony to be held in Norway. The ritual may very well have included some references to the crusades of his father Erling and maternal grandfather King Sigurd jórsalafari. ${ }^{216}$ The Church also gave the dynasty

214 Erling's rise to power was also connected to the death of his half-brother, Ogmund dengje, while he was on crusade. After his return, Erling became one of the leading figures around King Inge, see Orkneyinga Saga, ch. 89.

215 The traditional practice in the period was that sons of a former king would claim the right to the throne. Magnus's claim, however, was through his mother Kristin, daughter of King Sigurd.

216 According to a later source, Bergen Rimkrønike (ca.1560), Magnus'coronation date was the feast day of St Lawrence [Lavranz messo], August 10, see Bergens Rimkrønike: Utg. efter håndskriftene: Med en undersøkelse av krønikens tilblivelse og kilder av Geirmund Vislie, ed. Geirmund Vislie, Småskrifter fra det litteraturhistoriske Seminar, Oslo: Mallingske, 1925. This is the same day 
ideological support, including crusading ideology in its defence against "rebels and criminals."217

On a more structural level, one aspect of the Norse campaign in the 1150s was that it established, or rather confirmed, the development of a Norse crusade tradition. Within the wider context of the crusades, the expedition of Earl Rognvald might, as mentioned, have been a late response to Pope Eugenius III's call for a general crusade. However, in a narrower, regional context, the expedition did in many ways represent both a continuation of an established crusade practice, as well as a shift within that same tradition. On the one hand, the expedition confirmed the centrality of Jerusalem, while not excluding other crusade venues. On the other hand, the expedition marked a shift towards stronger aristocratic involvement in Norse crusade expeditions. The crusades would still enjoy strong royal support following centuries, but participation was now to be predominately an aristocratic undertaking. ${ }^{218}$ Nevertheless, royal patronage played an important role in the recruitment and organisation of Norse crusade expeditions, with elements of crusading ideology incorporated into secular and canon law in the 1160 s.

Another structural tendency was the intensified process of translation - through relics and architecture - which made Nidaros more closely associated with Jerusalem. The translation was not only carried out by stones and bones, it could also be expressed as a in a more "Norse kind of way." In connection with the elevation of Nidaros to archiepiscopal see in 1152/53 - coincidentally during the pontificate of the instigator of the Second Crusade, Eugenius III - an assembly was held in Nidaros cathedral. ${ }^{219}$ Present at the occasion, perhaps as part of the first Olsok ("Olaf's Wake") celebration there, were the three kings, Eystein, Sigurd and Inge, as well as the first archbishop of Nidaros, Jón Birgisson (d. 1157). It was also on this occasion that the Icelandic priest and skald, Einarr Skúlason, first performed his famous poem, Geisli [Ray of light], a celebratory poem of the Norwegian martyr-king St Olav (d. 1030). ${ }^{220}$ Einarr, who in other poems had praised King Sigurd jórsalafari's crusade exploits, now presented a motive that was to become very common, the comparison between Christ and St Olav. The association between Olav and Christ was

mentioned in connection with Earl Rognvald and Erling's visit to, and bath, in Jordan, Orkneyinga Saga 1978: ch. 88, where King Sigurd also had been.

217 Sverre Bagge, From Viking Stronghold to Christian Kingdom. State Formation in Norway, c. 900-1350 (Copenhagen: Museum Tusculanum Press, 2010), 59-61.

218 This was the case for the Danish-Norwegian crusade in the early 1190s and for the many smaller contingents that set sail from Norway in 1216 to join the crusade proclaimed at the Fourth Lateran Council, see Svenungsen, "Norge og korstogene,” 34-149.

219 Johnsen, Studier vedrørende kardinal Nicolaus Brekespears legasjon, 40-64.

220 Cf. Chapter 14 (Øystein Ekroll), 281. For the poem, see Einarr Skúlason's Geisli: A Critical Edition, ed. M. Chase, Toronto: University of Toronto Press, 2005. 
further underlined by the very building in which the performance took place, along with the presence of the Cross relic. ${ }^{221}$ Simultaneously as these events took place in Nidaros, Norse crusaders were on their way to Jerusalem. This all formed part of a process of translation, to create a Jerusalem in the North.

221 The church in Nidaros was built during the reign (1066-1093) of King Olav III kyrri (the peaceful), and dedicated to the Holy Trinity (Christchurch). See Chapter 14 (Øystein Ekroll), 270-98. 